\title{
Towards mitigation of greenhouse gases by small changes in farming practices: Understanding local barriers in Spain
}

Berta Sánchez $^{(1)}$, Jorge Álvaro-Fuentes ${ }^{(2)}$, Ruth Cunningham ${ }^{(1)}$, Ana Iglesias $\left.{ }^{(1)}{ }^{*}\right)$

(1) Department of Agricultural Economics and Social Sciences, Universidad Politécnica de Madrid, Madrid, Spain

(2) Department of Soil and Water, Estación Experimental de Aula Dei (EEAD), Consejo Superior de Investigaciones Científicas (CSIC), Zaragoza, Spain

${ }^{(*)}$ Corresponding Author

Ana Iglesias

Dept. of Agricultural Economics and Social Sciences, Universidad Politécnica de Madrid. Avenida de la Complutense, sn. 28040 Madrid, Spain

Tel: +34913365 794 / + 34914524 900, extension 1914

Fax: +34 914524818

Email: ana.iglesias@upm.es

Type of article: full paper 


\section{ABSTRACT}

Small changes in agricultural practices have a large potential for reducing greenhouse gas emissions. However, the implementation of such practices at the local level is often limited by a range of barriers. Understanding the barriers is essential for defining effective measures, the actual mitigation potential of the measures, and the policy needs to ensure implementation. Here we evaluate behavioural, cultural, and policy barriers for implementation of mitigation practices at the local level that imply small changes to farmers. The choice of potential mitigation practices relevant to the case study is based on a literature review of previous empirical studies. Two methods that include the stakeholders' involvement (experts and farmers) are undertaken for the prioritization of these potential practices: (a) Multi-criteria analysis (MCA) of the choices of an expert panel and (b) Analysis of barriers to implementation based on a survey of farmers. The MCA considers two future climate scenarios - current climate and a drier and warmer climate scenario. Results suggest that all potential selected practices are suitable for mitigation considering multiple criteria in both scenarios. Nevertheless, if all the barriers for implementation had the same influence, the preferred mitigation practices in the case study would be changes in fertilization management and use of cover crops. The identification of barriers for the implementation of the practices is based on the econometric analysis of surveys given to farmers. Results show that farmers' environmental concerns, financial incentives and access to technical advice are the main factors that define their barriers to implementation. These results may contribute to develop effective mitigation policy to be included in the 2020 review of the European Union Common Agricultural Policy.

Keywords: Barriers to adoption; Farming practices; Mitigation practices; Multi-criteria Analysis; Surveys 


\section{INTRODUCTION}

Greenhouse gas (GHG) emissions as a consequence of human activities are causing alterations in the climatic system (Pachauri and Reisinger 2007). The levels of gases in the atmosphere define changes in the climatic systems that in turn define the impact on society and the environment. Responses to face climate change include two kinds of policy intervention: mitigation and adaptation (Fisher et al. 2007). Mitigation refers to actions that reduce GHG emissions and enhance so called carbon sinks to limit long-term climate change. Mitigation policy is greatly influenced by barriers to behavioural change (Stern 2007; OECD 2012). Adaptation refers to actions that help society and the environment to adjust to climate change consequences. Adaptation policy actions should not result into GHG emissions increases, and thus must consider their mitigation potential (Klein et al. 2007).

Agriculture is an important source of GHG emissions, contributing approximately $10-12 \%$ of global anthropogenic GHG (c.a. $6.1 \mathrm{Gt}$ of carbon dioxide $\left(\mathrm{CO}_{2}\right)$ equivalent (eq) per year in $2005)$ and accounting for about $47 \%$ of methane $\left(\mathrm{CH}_{4}\right)$ and about $58 \%$ of nitrous oxide $\left(\mathrm{N}_{2} \mathrm{O}\right)$ (Smith et al. 2007b). On a global scale, the main sources of GHG released from agriculture are: (i) the significant amount of $\mathrm{CH}_{4}$ mainly from livestock (enteric fermentation) and from rice cultivation (ii) the considerable quantity of $\mathrm{N}_{2} \mathrm{O}$ mainly from soils emissions and manure management; and (iii) the $\mathrm{CO}_{2}$ from decay or burning of plant litter and soil organic matter (Smith et al. 2008; UNFCCC 2008; Snyder et al. 2009).

As a consequence of global mitigation policy, European agriculture has to face new policy objectives derived from the need to reduce GHG emissions. The United Nations Framework Convention on Climate Change (UNFCCC) process recognizes the significant role of agriculture in the global efforts to deal with climate change and to stabilize GHG concentrations in the atmosphere. The commitments and responsibilities agreed by the UNFCCC Kyoto Protocol include the development, dissemination and adoption of mitigation practices that 
reduce GHG emissions from agriculture (UNFCCC 2008). Loosely speaking, the European Union (EU) shares a collective target to reduce GHG emissions by $20 \%$ compared to their 1990 levels by 2020, with different individual targets depending on their emission levels (EEA 2010). The European Trading Scheme (ETS) regulates these emissions but it does not cover the diffuse sectors such as agriculture or transport. The diffuse sectors in the EU are subjected to emissions control measures by the individual Member States' limits for approximately $10 \%$ emissions reduction in 2020 compared to the 2005 baseline (Böhringer et al. 2009). Member State GHG emission limits for Spain are 10\% by 2020 compared to 2005 GHG emission levels (EC 2009a).

The adoption of agricultural practices for GHG mitigation is a challenge for European farmers and farming advisers (Iglesias et al. 2012b). Although the advisor's knowledge related to sustainable soil management is very comprehensive (Soane et al. 2012), farmers' attitudes and concern about GHG mitigation need further understanding in order to reach standardized practices that meet the new policy objectives (Ingram and Morris 2007). Agricultural management and mitigation practices to reduce greenhouse gases have been widely researched (Smith 2004; Aguilera et al. 2013), but there is a lack of knowledge on what cultural and social factors (such as education, information and traditional local practices, amongst others) and policy incentives have an effect on the implementation of mitigation measures (Prager and Posthumus 2010; OECD 2012). In conclusion, further research is needed on barriers to adoption of the mitigation practices, effectiveness of mitigation potential of the adopted practices and the influence of climatic trends, economic conditions and farmer's behaviour regarding mitigation practices adoption (Smith et al. 2007b).

The goal of this research is to assess the mitigation practices adopted by farmers at the local level and its relation to farmer specific features. This study addresses crop and soil mitigation measures and livestock is not explicitly considered. It examines the case of Aragon in Spain, a region with extensive agricultural activity, representing $10 \%$ of the Spanish total utilized agricultural area (EUROSTAT 2013). The research provides results on potential agricultural 
measures for mitigation and the barriers and incentives for their adoption at the local level. We aimed to contribute to policy development and to transfer the information to farmers' advisory services. To reach this objective, the following three tasks were carried out. First, we reviewed the state of the art of scientific knowledge on GHG mitigation measures in order to select the agricultural practices for our case study based on their mitigation potential. Second, in order to address the suitability of the selected mitigation practices, a prioritization was built based upon consultation with an expert panel and by carrying out a Multi-criteria Analysis (MCA) of their responses under two different climate scenarios. Finally, we tested the implementation of the selected mitigation practices at the local level in the case study area by conducting a widesurvey and we assessed the factors which influence the adoption by farmers of these practices by conducting an econometric analysis.

\section{DATA AND METHODS}

\subsection{Methodological approach}

Our methodological approach included three components to build a multi-disciplinary methodology (Figure 1):

(1) The mitigation potential of agricultural practices was evaluated by reviewing experimental evidence of soil and crop management practices that reduce GHG emissions. The data collection in our case study area took information from existing publications and studies, analysing the agronomic experimental evidence. The result was a selection of practices that have a greater potential for mitigation.

(2) The suitability of these selected practices was then evaluated by MCA. The data for this evaluation was derived from questionnaires given to an expert panel. The result was a list of the selected practices based on the priorities given to social, economic and environmental factors. 
(3) Based on farmers' responses from a survey in the case study region, an econometric analysis was undertaken to estimate the likelihood of adoption of the selected mitigation practices. This probability was calculated as a function of attitudes and farming characteristics of farmers. The result was an analysis of the barriers and incentives for adopting mitigation practices based on the outcome of the model.

[INSERT FIGURE 1 NEAR HERE]

The multi-disciplinary methodology accomplished for this research builds an analysis based on the combination of different methods. There is no direct link between the MCA analysis and the econometric modelling methodologies. The MCA serves to evaluate the results of the preliminary literature review on mitigation practices and to identify the most suitable mitigation practices that could be adopted to facilitate the GHG mitigation to expected climate change. The econometric analysis based on surveys to farmers serves to identify the primary mitigation practices already in place in the case study and to assess the different socioeconomic factors that influence the adoption of those measures by farmers. Both methodologies share the stakeholders' involvement (experts and farmers) and they are complementary to approach a mitigation strategy to promote the adoption of suitable practices at the local level.

The results obtained from the analysis provided valuable information that could be used to propose recommendations for mitigation policy development and farmers' advisory services in agriculture under varying climate change scenarios. 


\subsection{Selection of mitigation practices for the case study}

The potential of reducing GHG emissions of soil and crop management practices was evaluated by reviewing agronomic experimental evidence. The data collection took information from existing publications and studies. A keyword search was performed in the major scientific databases such as Web of Science, Agris, Agricola and Google Scholar. We collected literature reporting agricultural practices for different geographical areas that show higher mitigation potential. The selection of practices that have a greater mitigation potential in terms of potential soil carbon sequestration rate are shown in Table 1 as well as the main sources considered for the selection. The study of mitigation practices has shown a broad spectrum of options that could apply to the Spanish case study. This spectrum reflects very different and sometimes conflicting views of priorities for adopting mitigation practices according to the variability of mitigation potential driven by different variables such as climate, soil type and/or cropping characteristics. Our case study is the region of Aragon, an intensive agricultural region located in the middle of the Ebro river basin in north-eastern Spain. In Aragón, agricultural activity is located in the central part since the region is bounded by two mountain ranges (i.e., the Pyrenees in the north and the Iberian range in the south). In the central part of the region where agriculture is concentrated, climate and soils are rather homogeneous with a prevailing Mediterranean continental climate and Entisols, Inceptisols and Aridisols as the main soil types (Herrero and Snyder 1997; Ninyerola et al. 2005; Badía 2011). These homogeneous conditions result in a low diversity of agro-ecological settings throughout the main agricultural areas of the region. We have selected the six most important practices according to the agronomic, climate and production factors for our case study.

Detailed below is the MCA of experts' choices that was carried out in order to evaluate and prioritize these selected practices taking into account socio-economic and environmental criteria. The selected practices from the literature review were also included in the surveys with farmers to then assess the barriers to the practices' adoption in the case study area of Aragon. 
The farmers were also asked for other relevant mitigation measures adopted by them, but there were no significant responses.

[INSERT TABLE 1 NEAR HERE]

\subsection{Prioritization of practices: Multi-criteria Analysis (MCA) of experts' choices}

In order to quantify suitability of the selected mitigation measures, a MCA was undertaken involving the different experts' priorities in order to arrive at an overall score (Georgopoulou et al. 2003; Konidari and Mavrakis 2007; UNFCCC 2011). A supporting tool was used to simultaneously account for the multiple qualitative criteria using the analytical hierarchy process (AHP). The tool is Web-Hipre software (Mustajoki and Hämäläinen 2000; Mustajoki et al. 2004) for decision analytic problem structuring, multi-criteria evaluation and prioritization.

Both 100 to 0 partial value scales and scaling constants were interactively defined based on qualitative value judgments of 18 experts. To supply a broad outline and make the scores robust, experts from different academic sectors of Spain were encouraged to give their input. The weighted sum of the evaluations of every practice over all criteria was computed by the software. The MCA provided composite expert prioritization and a ranking of the practices on the basis of the weighted sum.

The evaluation and prioritization of mitigation choices for the study was based on the results of the literature review of mitigation practices and expert input gathered through a participatory process. A questionnaire was developed and personally implemented with an expert panel in February 2013. The group consisted of eighteen experts from different academic sectors each holding stakes in agriculture mitigation practices to reduce GHG, including representatives from 
regional and national research institutes and universities. The requirements for the expert selection were: i) the expert performs research work; ii) the expert has been working on issues related to GHG mitigation in agriculture for a minimum of five years; iii) it was desirable that the experts had regular contact with farmers and extensive knowledge of the productive sector; and iv) the experts had sufficient knowledge of the different cropping systems and management to cope successfully with the six selected mitigation practices contained in the survey.

The aim was to gather information on experts' perception of the six selected mitigation practices in agriculture faced with both a current and a changing climate. To ensure a common understanding by the experts of the criteria and ensure that comparability of the results from the experts' scores, we conducted personal interviews with each of the experts. For the data input collection, the questionnaire was divided into two sections. A complete description of the six selected practices was provided to the experts in the questionnaire (see Appendix 1). The experts were advised with examples and guidelines about the criteria's meaning and how to fill in the questionnaire during the interviews. First, the experts were asked to assign values according to their priorities for the implementation of each mitigation practice on the overall feasibility criteria. The mean values resulted in a ranking of the expert's priorities for the overall feasibility of the six selected mitigation practices. The implementation was assessed on the farm level. The feasibility was measured in terms of importance for GHG mitigation and desirability for economic, social and environmental farm benefit. The scoring scale for the overall feasibility criteria ranged from 0 to 100 , whereby 0 indicated the lowest importance and desirability and 100 indicated the highest. Then the experts were also asked to allocate weights to the evaluation criteria representing their priorities. These criteria were distributed into three main groups: economic, social and environmental. The experts were required to assign weights to the three groups and further to the evaluation criteria within each group. The criteria were measured in terms of importance for GHG mitigation and desirability for economic, social and environmental farm benefit. The scoring scale for the three main groups and for the thirteen 
criteria within the groups ranged from 0 to 100 , whereby 0 indicated the lowest importance and desirability and 100 indicated the highest. Second, the adoption effect of the selected mitigation practices was evaluated by the experts weighting the thirteen criteria under two future scenarios. These scenarios were classified as a current climate scenario with similar climate conditions to those at present and as a climate change scenario with drier and warmer conditions based on the most likely projection according to CEDEX (2011) for Spain (a decrease in average annual rainfall of $8 \%$ and an average increase in temperature of 2 degrees Celsius by the 2040s). The scoring scale ranged from -100 to $100,-100$ indicated a high negative effect and 100 indicated a high positive effect of the practice for the criteria. The results of the criteria scoring were also weighed to generate an evaluation matrix with practices in rows and criteria in columns, representing the priorities of the experts.

Finally, the analysis of composite expert priorities was computed by the Web-Hipre software including the weighted sum of the evaluations of every practice over all criteria. The analysis of composite expert prioritization provided a prioritization of the practices under the two scenarios on the basis of the weighted sum. The results showed the priority ratios per group of criteria and for every practice considered. The additive value function used to aggregate the component values (Mustajoki and Hämäläinen 2000) is expressed as follows in equation (1): (1) $V_{j}(x)=\sum_{i=1}^{n} w_{i j} v_{i j}(x)$

Where the overall value of the mitigation practice per group of criteria is $V_{j}(x)$. The group of criteria is $j$ (environmental, social or economic), the number of criteria is $\mathrm{n}$ and $w_{i j}$ is the weight of criteria $i$ of the group $j$. The rating of the mitigation practice $x$ with respect to the criteria $i$ of the group $j$ is expressed as $v_{i j}(x)$. The weights of the criteria $w_{i j}$ mean the relative importance of criteria $i$ of the group $j$ changing from its worst level to its best level, compared to the changes in the other criteria (Mustajoki et al. 2004). 
The experts' criteria against which the selected mitigation practices were to be evaluated are detailed below (Figure 2):

(1) Economic criteria group: CAP subsidies criteria refers to the extent of a practice's dependence on subsidies granted by the Common Agricultural Policy (CAP); the Yield variability criterion evaluates possible changes in crop yields (increases or decreases) implicated by the implementation of the practice; the Job creation criterion assesses the practice's capacity to create more farm employment and thus the promotion of sustainable economies and higher incomes and employment opportunities to the agricultural sector; Implementation criterion evaluates the additional cost of implementing the practice to the farmer; the Economic feasibility criterion evaluates the practice's feasibility in terms of economic profit margin (increases or decreases of net income due to practice adoption).

(2) Social criteria group: the Rural development criterion refers to the extent of the practice's influence on rural development. Rural development criteria is understood as a developmental model for the agricultural sector that corresponds to the needs and expectations of the society at large, and reconfigures rural resources to achieve wider rural development benefits. It must add welfare and high quality conditions to the employment in the agricultural sector to avoid its marginalization (Marsden and Sonnino 2008); the Farmer cooperation criterion assesses the extent to which the practice encourages cooperation between farmers, since the management of some of these practices is often linked to farmer cooperatives and organizations; Farmer training criterion estimates the extent to which the practice promotes a higher level of farmer training, since to be able to implement some of these practices the farmer will have to undergo technical training; the Transfer technology criterion assesses the extent to which the practice contributes to development and transfer technology, since the flow of information between farmers and scientist will rise according to the wider adoption of the practice. 
(3) Environmental criteria group: the Mitigation potential criterion assesses the practice's capacity to reduce GHG emissions; the Soil quality criterion estimates the practice's capacity to enhance soil quality; the Water quality criterion estimates the practice's capacity to enhance water quality; the Ecologic value criterion evaluates the additional ecologic value of implementing the practice.

[INSERT FIGURE 2 NEAR HERE]

\subsection{Survey design and data}

The study was complemented by a survey conducted in the region of Aragon to assess the farmer's barriers and motivation to adopt mitigation practices by conducting an econometric analysis of farmers' responses. This section of the study examines the case of Aragon, an intensive agricultural region located in the middle of the Ebro river basin in north-eastern Spain. Aragon is the fourth largest region of Spain with 4,770,054 ha and the land is largely dedicated to agriculture with approximately 1,300,763 ha of crop land and 324,354 ha of pasture and grassland (MAGRAMA 2013). The main farming system of the Aragon region is field crops and the main cultivated crops are barley (Hordeum vulgare L.) (452,839 ha), wheat (Triticum aestivum L.) (284,713 ha), alfalfa (Medicago sativa L.) (99,079 ha) and maize (Zea mays L.) (63,884 ha) among field crops and olives (Olea europaea L.) (59,477 ha) and vineyards (Vitis vinifera L.) (37,425 ha) among permanent crops (MAGRAMA 2013). In Aragon, about 25\% of the total agricultural land is irrigated. Irrigated areas are mainly located in the centre of the region where water-limiting conditions are present. Annual precipitation ranges from $300 \mathrm{~mm}$ in the central part of the region up to $2000 \mathrm{~mm}$ in the Pyrenees. However, the majority of the 
region is within the range $300-800 \mathrm{~mm}$ of annual precipitation. Air temperatures also vary significantly with mean annual temperatures ranging from $7^{\circ} \mathrm{C}$ to $15^{\circ} \mathrm{C}$ (Ninyerola et al. 2005).

For the main crops grown in Aragon (i.e., barley and wheat in dryland conditions), agricultural management consists in the use of intensive tillage systems to prepare planting, high fertilization rates mainly with mineral fertilizers and frequent use of herbicides to control weeds. According to data from 2012, intensive tillage in Aragon is still frequent; in fact the no-tillage system is currently only implemented by $10 \%$ of the area (MAGRAMA 2013). Mineral fertilizers are still the main nitrogen source but organic fertilizers are gaining significance in the area since there is a growing intensive livestock sector in the region (Yagüe and Quílez 2010).

Aragon accounted for 4.8\% of total GHG emissions of Spain in 2010 and the agricultural

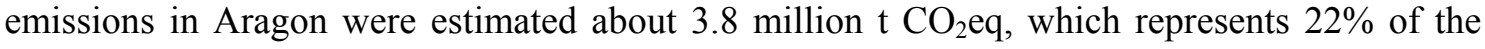
total anthropogenic emissions in the region (16.9 million $\mathrm{C}_{2} \mathrm{eq}$ ) (MAGRAMA 2012). Crop cultivation released almost 1.85 million $\mathrm{CO}_{2}$ eq due to nitrous oxide emissions $\left(\mathrm{N}_{2} \mathrm{O}\right)$ from crop and soil management. Furthermore, a recent case study identified Aragon as an intensive agricultural area in terms of emissions and accordingly assessed a number of GHG mitigation measures (Kahil and Albiac 2013).

The input data for the econometric analysis were collected via a face to face survey of 128 farmers of Aragon in order to avoid non-response caused by non-contact and generate a greater diversity of answers (Czaja and Blair 2005; De Leeuw 2005). Prior to the survey with the farmers, the questionnaire was tested by a group of qualified respondents to ensure questions were well worded and were relevant to the proper audience. The surveys were conducted at two meeting points for Aragon's farmers, places where the farmers usually go to buy farming supplies or to do paperwork and the selection was made on a "show-up" basis. The surveys were carried out across different days during March 2013. The sample included farmers with 
holdings covering different areas in Aragon (Figure 3), but it is worth noting that this sample is not necessarily representative of the entire region of Aragon.

All farmer respondents were crop producers $(100 \%)$ and some combine crop production with livestock activity (35\%). The majority of the farmers were male $(92 \%)$ and over 36 years of age (84\%). However, only a little over half of the farmers had completed a technical degree (58\%) or had received training about the management practices $(54 \%)$. The proportion of farmers that had received training about the CAP was less than one quarter $(23 \%)$. In relation to land ownership, $63 \%$ of farmers were owners of their farm land, $43 \%$ of farmers had more than 100 ha, $24 \%$ had between 50 ha to 100 ha, $20 \%$ had between 10 to 50 ha and $13 \%$ had fewer than 10 ha.

\section{[INSERT FIGURE 3 NEAR HERE]}

The survey was composed of 16 questions in total including check-all and forced-choice questions. In the survey participants were asked questions relating to (i) farmer characteristics such as sex, age or education; (ii) production characteristics such as size of holding, irrigation intensity or type of ownership; (iii) the current adoption of the selected mitigation practices; (iv) institutional factors such as subsidies received and advice; and (v) farmers' concern such as agricultural policy or environmental concern for the adoption of mitigation practices.

\subsection{Models specification}

The adoption of the best agricultural practices is the objective of many economic studies to explore the key determinants of this decision (Prager and Posthumus 2010; OECD 2012). In 
each case it is necessary to identify the most appropriate econometric tool in order to measure the influence of cultural, social or economic factors in the adoption decision. The decision making process to assess the adoption of mitigation practices in this study has been divided into two analyses: the intensity of adoption and then the rate of adoption for each individual mitigation practice. Different econometric models have been used in order to determine what are the most relevant factors influencing the mitigation practices adoption in our case study: (i) a logistic Poisson and a Negative Binomial regression which are count data models to determine the factors affecting the adoption intensity (Rahelizatovo and Gillespie 2004; Isgin et al. 2008); and (ii) a logit binomial to determine the relevant factors for each individual mitigation practice (Johnson et al. 2010; Ward et al. 2008).

The Poisson regression model can be considered the starting point for count data analysis. In our case of study, the Poisson model is used to model the number of occurrences of the event of interest and the adoption of the selected mitigation practices is our event of interest (Cameron and Trivedi 2005; Gujarati and Porter 2009). The associated density function is expressed as in the following equation (2).

(2) $f\left(y_{i} \mid x_{i}\right)=\frac{e^{-\mu} \mu^{y}}{y !} y_{i}=1,2, \ldots$,

Where $y_{i}$ is the adoption intensity of the selected mitigation practices by farmer $\mathrm{i}$ and $x_{i}$ are variables that affect the adoption of these practices. The factorial parameter $y$ ! is split as $y !=y *(y-1) *(y-2) * 2 * 1$ whereas the mean parameter or intensity $\mu_{i}$ represents the expected number of events and is expressed as in equation (3).

(3) $\mu_{i}=E[y i \mid x i]=\exp \left(X_{i}^{\prime} \beta\right)$

The Poisson regression model is estimated by maximum likelihood. Some important conclusions are derived from the marginal effect concept, meaning that the change in the conditional mean of $y$ when the regressors $x$ change by one unit (4). 
(4) $\frac{\partial E[y \mid x]}{\partial x}$

A negative binomial analysis as a statistical test has been carried out to allow an adjustment for the presence of over-under dispersion (variance of $y_{i}$ greater or lower than its mean value) after running a Poisson regression. Overdispersion might mean that the regression experiences problems with inconsistency, deflated standard errors and grossly inflated t-statistics in the maximum likelihood output.

A binomial logit model was specified to estimate the likelihood that given farmer and production characteristics and farmer behavioural traits would affect the probability of farmers adopting each specific selected mitigation practice. The logistic distribution function represents a generalized form of the model for each dependent variable (5) (Cameron and Trivedi 2005; Gujarati and Porter 2009):

$\operatorname{Prob}($ Farmer $i$ adopts considered mitigation practice $)=P=\frac{e^{Z}}{1+e^{Z}}(5)$

Where $Z_{i}=\beta_{1}+\beta_{2} * X_{i}$ and $X_{i}$ are the logit model independent variables chosen for the regression.

As long as $Z_{i}$ is between $-\infty$ to $+\infty$ the probability the farmer adopts the considered mitigation practices is placed between 0 and 1. As written in Equation (6), the logit model implies that the logarithm of the ratio is linearly related to $X_{i}$. Hence, when the logit result is positive, the more the value of the regressor increases and the more likely the value of the regression is closer to one.

(6) $L_{i}=\ln \frac{P_{i}}{\left(1-P_{i}\right)}=\beta_{1}+\beta_{2} * X_{i}+\mu_{1}$ 


\subsection{Variables influencing farmers' decision to adopt mitigation practices}

This section discusses variables that are hypothesized to influence the adoption of mitigation practices and are used in the econometric models. While the adoption literature has covered a wide range of causation factors affecting the adoption of best agricultural practices and technology (Rahelizatovo and Gillespie 2004; Johnson et al. 2010; Isgin et al. 2008; Ward et al. 2008), there is limited research investigating the specific determinants affecting adoption of mitigation and adaptation practices to climate change (Cary et al. 2001, Prager and Posthumus 2010; OECD 2012; Tambo and Abdoulaye 2012; Archie 2013). The explanatory variables used in this study to explain adoption decision are based on both the theoretical and empirical literature of agricultural practices adoption. The implementation of new practices is closely related to innovation or implementing a new idea (Feder and Umali 1993). For example, age and education are essential determinants to innovation (Kivlin and Filegel 1966) and to agricultural innovation (Feder and Umali 1993; Sundind and Ziberman 2001). At the same time, there is considerable literature on attitudes of the public towards environmental commitment and climate change (Eurobarometer Survey on Climate Change 2011) and on people's support for climate change policies (Bryan et al. 2009; Garcia de Jalon et al. 2013; Hanemann et al. 2011). This broad range of studies support the idea that implementation of new choices is determined by a common set of individual characteristics. Therefore here we have selected a set of factors that are closely related to innovation and environmental commitment. The explanatory variables fall under four categories: farmer characteristics, production characteristics, institutional factors and farmers' concerns. Table 2 summarizes the descriptive statistics of the variables in the empirical models.

The different factors of mitigation practices adoption may explain more or less effectively the adoption decision facing the farmer. The adoption of mitigation practices varies according to several technical requirements (e.g. machinery, agro-chemicals, fertilisers, seeds), economic requirements (e.g. labour, investment) and consequently results in different risks levels for the 
farmer. Therefore the factors that influence the range of practices that the study considers are expected to vary among practices. For example, the importance of subsidies varies among practices and so does the additional level of private investment. Education may be linked to technical knowledge required for implementation. The adoption and the hypothesized explanatory variables were assumed to have a log-linear relationship, the adoption in the logarithmic form and the explanatory variables in the linear form, according to the following studies. We consider the age and education of the farmers which has been known to influence the decision to adopt mitigation practices (Johnson et al. 2010; Rahelizatovo and Gillespie 2004; Isgin et al. 2008; Ward et al. 2008; Tambo and Abdoulaye 2012; Archie 2013). The ownership of land (Landowner) was also supposed to have a noteworthy effect on the farmer's willingness to implement mitigation practices (Prager and Posthumus 2010; Knowler and Bradshaw 2007). Based on previous studies, the farm size in hectares of cropped land was considered a significant factor influencing the adoption of mitigation measures (Norris and Batie 1987; Knowler and Bradshaw 2007; Isgin et al. 2008; Tambo and Abdoulaye 2012). Furthermore we looked at the irrigation intensity, known to play an important role in the farm production, and hence was assumed to have a significant influence on the decision to adopt mitigation practices or not. Financial incentives (Subsidies) were presumed to be highly significant determinants of adoption decisions also.

Techadvice and Pacadvice were also considered as influential factors representing respectively levels of technical and policy advice received regarding training and information about new practices and changes in related agricultural policy. Prager and Posthumus (2010) pointed out that concern and knowledge of agricultural policy and legislation represents a significant determinant to encourage attitude change (Awareness1). Literature reviewed also showed the importance of having environmental motivation or climate change awareness (Awareness2) to increase the adoption of mitigation practices (Morris and Potter 1995; Prokopy et al. 2008; Tambo and Abdoulaye 2012). 
In summary, all our variables were hypothesized to influence the probability of a farmer adopting the mitigation practices under consideration. They were also hypothesized to have a positive impact on adoption decisions, except the age of the farmers which was hypothesized to have a negative effect.

[INSERT TABLE 2 NEAR HERE]

\section{RESULTS AND DISCUSSION}

\subsection{Expert priorities of mitigation practices}

The participatory process (expert's panel and questionnaire) provided a ranking of the feasibility for the implementation of the selected mitigation practices (Figure 4). The percentages were distributed as follows: intercropping $(67 \%)$, crop rotations $(64 \%)$, fertilization with animal manures $(62 \%)$, zero/reduced tillage $(61 \%)$, optimized fertilization $(55 \%)$ and cover crops in orchard systems (41\%). Most of the practices showed similar percentages except that of cover crops in orchard systems. The fact that this practice was less favoured by the experts may be related to the relatively small area dedicated to permanent crops compared with cereals ( $34 \% \mathrm{vs}$. $66 \%$ out of Spain). It may further be influenced by the current extent of knowledge on cover crops in orchard systems compared with the other practices proposed which have been more extensively studied and more widely understood in Spain (MAGRAMA 2013). Thus, the experts chose intercropping and crop rotation as their preferred practices in terms of their feasibility potential. This may be due to the similarity between intercropping and crop rotations in terms of management requirements and benefits achieved in GHG mitigation. They are agricultural practices that may be implemented immediately and help to mitigate GHG emissions with relatively low-cost and no major technological requirements. The multiple 
benefits associated with the adoption of these two practices have generated widespread social acceptance and scientific consensus. West and Post (2002) analysed a global database of 67 long term experiments and reported that enhancing crop rotation may sequestrate an average $20 \pm 12 \mathrm{~g} \mathrm{~m}^{-2} \mathrm{yr}^{-1}$ of soil organic carbon (SOC). Lal (2004) reported positive effects from rotations based on appropriate cover crops or pastures for enhancing SOC concentration. Other studies (Lal and Bruce 1999; Paustian et al. 1997; Lal 2004) found that benefits on SOC increases and $\mathrm{C}$ sequestration may be accentuated when using intercropping due to more efficient nutrient use and reducing fertilizers application rate.

The allocation of the criteria weights was determined by the experts' priorities of the three main groups: environmental, economic and social. These were distributed as $44 \%, 35 \%$ and $21 \%$ respectively. Within the environmental group, the most valued criteria were the mitigation potential criterion and the soil quality criterion (Table 3 ).

[INSERT TABLE 3 NEAR HERE]

The results of the analysis of expert composite priorities (Figure 5) showed similar trends between experts' priorities for both the current climate and the climate change scenario. Experts showed greater acceptance of practices such as optimized fertilization and cover crops and minor acceptance in the practice of fertilization with animal manures according to this analysis.

[INSERT FIGURE 5 NEAR HERE] 
For both climate scenarios considered, mitigation practices that showed higher scores for most of the criteria were optimized fertilization and cover crops reflecting a greater positive effect on GHG mitigation by implementing them. Optimized fertilization stood out for its capacity to enhance water quality and the extent to which the practice's adoption would contribute to develop and transfer technology (Smith et al. 2007a; Snyder et al. 2009). Moreover, it has been observed that when fertilizer was used more efficiently soil C sequestration is enhanced (Follet, 2001). In relation with the capacity of cover crops in orchard systems, it was also noted the capability to enhance both soil quality and the additional ecologic value for implementing the practice. Improvements in the soil organic matter content, microbial biomass $\mathrm{C}$, and the microbiological function have been reported under this practice (Steenwerth and Belina 2008). Thus, the potential for $\mathrm{C}$ sequestration with this practice is significant and noteworthy particularly in Mediterranean agroecosystems (Nieto et al. 2013).

The MCA analysis under current climate scenario also showed a negative effect of the capacity of zero tillage to create more farm employment, since the adoption of this practice may reduce the labour needs. The adoption of reduced/ no-tillage practice has been widely highlighted for their mitigation potential (Lal and Kimble 1997; Lal and Bruce 1999; Follet 2001; Ogle et al. 2005; Álvaro-Fuentes and Cantero-Martínez 2010). The success of the practice has been associated with the advance in weed control methods and farm machinery (Smith et al. 2008) thus reducing the need for manual labour. Besides, the adoption of reduced/ no-tillage practice showed high benefits on the soil quality and low costs of implementation for the farmers. Concurrently, the MCA analysis under current climate scenario showed a negative effect of fertilization with animal manure on the additional cost of implementing the practice and on water quality. Fertilization with animal manures demands large management requirements such as improved storage and handling and it could have adverse effects due to higher costs (Smith et al. 2007a). In addition the cost associated with the application of the animal manure in the field (labour and fuel) can make fertilization with animal manure a more expensive practice than 
mineral fertilization. The MCA analysis also highlighted the beneficial effect of fertilization with animal manure on its capacity to enhance soil quality and crop yields, as well as the extent to which the adoption of this practice would contribute to develop and transfer technology. However, this practice should be taken with caution since despite there is a positive mitigating effect of applying fertilization with animal manures on reducing $\mathrm{CO}_{2}$ emissions, there could be increases on $\mathrm{N}_{2} \mathrm{O}$ emissions and negative effects on water quality (Smith et al. 2008).

For the climate change scenario, under a drier, warmer climate the need for these practices will be greatly increased, hence the reluctance to adopt them will be diminished and the relative benefits associated with their implementation more pronounced (Álvaro-Fuentes and Paustian 2011; Iglesias et al. 2012a; Aguilera et al. 2013). Although all scores increased, adoption of optimized fertilization and cover crops still had the greatest positive effect. The negative effect of implementation cost and water quality was reduced for fertilization with animal manure, which although beneficial under current climate conditions, will be more worthwhile under the climate change as predicted and so it will be the investment in this change of practice. The dual role of some of these practices in mitigation and adaptation reinforces the need for adoption under the climate change scenario, as is the case of the direct seeding/reduced tillage practice which encourages the retention of water soil content whilst reducing GHG emissions.

We have synthesised results in a simple qualitative ratio of the effort (level of costs to farmers) to benefit (potential mitigation benefit) of the different mitigation measures listed in Table 1. Based on the expert responses under the two scenarios, cost marks were assigned 1, 2, 3 and 4 values for the calculation. Figure 6 summarizes the effort to benefit ratio (y axis) for the mitigation measures (x axis). In general, measures that present a higher effort to benefit ratio, also show a higher level of uncertainty, such as the case of the measures for reduced tillage and fertilization with animal manures. The measures that are more widely accepted by experts have a relatively low effort to benefit ratio, but in contrast they show less uncertainty, suggesting that synergies decrease the uncertainty. 
[INSERT FIGURE 6 NEAR HERE]

\subsection{Farmers' response to adopt mitigation practices}

Recent studies have focused their interest on the wider range of motivations for farmers' decisions that can improve the adoption of agricultural practices with significant mitigation potential of GHG emissions (Cary et al. 2001; OECD 2012). Since financial incentives, education, information and production characteristics influence the outcome of policy incentives, more attention needs to be paid to the knowledge on how these factors influence the adoption of mitigation practices at local level to facilitate the work of European policy makers (Prager and Posthumus 2010).

\section{Level of mitigation practices adoption}

The percentages of sampled farmers adopting each of the mitigation practices considered for the analysis are detailed in Table 4 . The most frequently adopted practice was crop rotation, with an adoption rate close to $69 \%$. This could be accounted for by the fact that the farmers of Aragon are aware that by rotating they can achieve higher benefits since this practice is economically motivated. The high adoption rate of crop rotation can be also explained by the widespread modernization of irrigation systems in field crops of Aragon (Lecina et al. 2010), because the farmers with modern sprinkler systems are more willing to rotate two crops per year (winter crop - cereal or leguminous and summer crop - maize) in order to obtain higher crop yields. There are also areas where alfalfa is widely grown for 4-5 years, which involves rotation of different crops at the end of this period for a similar time. Reduced tillage / no tillage and fertilization with animal manures were relatively frequently used mitigation practices, being adopted at rates of approximately $63 \%$ and $51 \%$ respectively. The practice of reduced tillage/no 
tillage is seemingly quite well promoted in the region by local cooperatives, agricultural associations, agricultural unions and research groups given its numerous benefits to both farmers productivity and environmental sustainability. In fact, Aragon is the second autonomous community of Spain with the largest adoption rate of direct seeding; representing $18.5 \%$ of the Spanish total (MAGRAMA 2013). The relative swiftness of its implementation coupled with support and advice from external groups has contributed to this being a favoured option of many farmers. With regard to the application of animal manure, it is worth noting that $35 \%$ of the farmers questioned combine both crop cultivation and livestock farming and thus the use of animal manure as fertilizer amongst these farmers and their neighbours is relatively prevalent. However in order for the practice to become more widespread, the manure must be available in sufficient quantities and at the appropriate moment and the application time and cost would have to be reduced significantly, otherwise it does not represent a worthwhile investment for the farmers concerned. Mitigation practices with adoption rates lower than $50 \%$ included optimized fertilization and intercropping. Cover crops in orchard systems seemed to be the lowest mitigation practice with approximately $22 \%$. However this small percentage can be accounted for by noting that in Aragon permanent crops are not widely practised. Whilst it could be a useful mitigation practice where applicable, in Aragon only $18 \%$ of the cropland is used for permanent crops such olive groves and vineyards (MAGRAMA 2013) and is as such, not as applicable in this region.

[INSERT TABLE 4 NEAR HERE]

Table 5 shows the frequency distribution of the number of mitigation practices by Aragon farmers sampled. The survey offers evidence that 115 farmers out of 128 in the sample had adopted at least one mitigation practice which implies a very high overall adoption rate close to 
$90 \%$. The sampled farmers adopted about 2.82 on average. Table 5 also demonstrates that only 13 (c.a 10\%) of these sampled Aragon farmers had adopted none of these mitigation practices, and thus it does not explicitly consider an excess zeros problem. While the majority $(83 \%)$ of the adopters had adopted 4 or fewer mitigation practices, only $17 \%$ of these farmers adopted 5 or more practices.

[INSERT TABLE 5 NEAR HERE]

Determinants of the intensity of mitigation practices adoption

The results of the Poisson and Negative Binomial models are shown in Table 6. The estimates associated with the marginal effects for the Poisson model are shown in Table 7

Table. The likeness value of mean (2.82) and variance (3.09) of the dependant variable Mitigatpractices (adoption intensity of mitigation practices) suggested the appropriateness of using the Poisson model due to the equality property of the mean and variance. To adjust the standard errors in the presence of overdispersion (the variance is larger than the mean), the method of estimating the maximum pseudolikelihood (robust standard errors) has been applied, providing the robustness of the Poisson to distribution misspecification. The results from the Poisson and Negative Binomial models were very similar.

[INSERT TABLE 6 NEAR HERE]

We performed the Wald statistical test to assess the significance of coefficients and the fit of the Poisson model with our dataset. The Wald test works by testing that all of the estimated 
coefficients are simultaneously equal to zero (Buse 1982). The null hypothesis that the coefficients are equal to zero would imply that no explanatory variable has an effect on the number of practices adopted. Based on the p-value associated with a chi-squared of 80.76 generated by the Wald test for the Poisson model, we can reject the null hypothesis at the given level of significance. This result indicates that the coefficients for our independent variables are not simultaneously zero and the inclusion of these variables helps to statistically improve the fit of the model.

Deviance and the Pearson goodness-of-fit chi-squared tests help to assess the fit of the model (Cameron and Trivedi 1986). We cannot reject the null hypothesis that our data are Poisson distributed since the tests are not statistically significant. Therefore, we conclude from these results that our model fits reasonably well.

Our results suggest that the factors that are positively influencing the farmer's decision to adopt or implement a greater number of agricultural practices are: advice on practices technology and management, advice on the CAP, economic incentives for the adoption of these practices and motivation or awareness of environmental type. We tested the correlations between the explanatory variables by practice and these factors were not significantly correlated in the model. However, the advice about the CAP and the economic incentives variables can be related since increases in the farmer's knowledge about the CAP from adequate sources might hence increase the incentives that the farmers are receiving thus far.

According to our study, keeping the other variables constant, if you increase the advice about the management of the practices, it is expected that mitigation practices adoption would increase significantly. In the same way, an increase in CAP advice would mean an increase in the mitigation practices adoption. These results concur with the studied literature (Cary et al. 2001; Prager and Posthumus 2010; Tambo and Abdoulaye 2012) which states that farmers who attended training courses and had access to technical and policy information adopted more 
mitigation practices. Further if environmental awareness (awareness2) was increased, it is expected that the mitigation practices adoption would also increase. The fact that increasing the awareness of climate change would lead to increased adoption of mitigation measures is concurrent with many previous studies (Morris and Potter 1995; Prokopy et al. 2008; Tambo and Abdoulaye 2012; García de Jalón et al. 2013).

This study showed that economic factors have a very significant impact on the adoption of mitigation practices by farmers surveyed in Aragón. For example, for an increase of subsidies, it is expected that the mitigation practices adoption would increase. Smith et al. (2008) showed that the economic limitations may be a strong barrier to the adoption of mitigation practices, reducing the agricultural GHG mitigation to less than $35 \%$ of the total biophysical potential by 2030. A broad range of research focuses on financial incentives measured as monetary compensation or subsidies by mitigating GHG emissions efforts, but behavioural barriers including educational, social and policy constraints have been found to limit the effect of economic incentives on adoption of mitigation practices (Prager and Posthumus 2010; OECD 2012).

The other variables involved in the equation, although not significant, showed a sign of regression coefficient in line with our assumptions, which may be due to the small number of collected observations.

[INSERT TABLE 7 NEAR HERE] 


\section{Determinants of individual mitigation practice adoption}

The logit binomial model provides a more detailed understanding of the factors influencing the adoption of agricultural mitigation practices. These results define the influence of the factors for each individually considered mitigation practice (Table 8).

Subsidies and Awareness2 (environmental motivation) seem to be key factors in the adoption of cover crops as hypothesized. However, the Landowner variable negatively affected the adoption of cover crops implying that our hypothesis was incorrect and that the fact of being a landowner in effect reduces the likelihood to adopt the practice of cover crops. However the limited extent of permanent crops in the sampled area may have affected this result.

The practice of reduced tillage and direct seeding seems to be more influenced by Age, Size, Techadvice and Pacadvice. This implies that older farmers are less likely to adopt the practices of reduced tillage and direct seeding, suggesting these relatively new practices are not seen as viable by more traditional farmers. This agrees with Cary et al. (2001) who found that younger farms are often more aware of soil degradation and so reducing tillage and directly sowing their seeds could be seen as advantageous to a young well informed farmer. Prager and Posthumus (2010) similarly noted a greater uptake amongst young farmers and larger farm holdings, concurrent with our results. As hypothesized, increased dissemination of information about the management of reduced tillage and more advice concerning relevant agricultural policy would incentivize the adoption of this practice.

The influence of Techadvice and Pacadvice seem to be common factors in the adoption of many mitigation practices, especially concerning optimized fertilization. This influence could be due to the close link between optimized fertilization, scientific advances, technological transfer and agricultural and environmental policy objectives. Furthermore, the influence of Techadvice seems to have a positive impact on the adoption of animal manure. These results reflect that 
which has been discussed previously regarding the technical knowledge required for the storage, handling and application of animal manure.

Crop rotation is positively influenced by Education, Subsidies, Pacadvice and Awareness2. This coincides with the relevant literature which has previously found that farmers with a technical education are expected to be more likely to adopt a mitigation practice (Rahelizatovo and Gillespie 2004; Knowler and Bradshaw 2007; Ward et al. 2008; Tambo and Abdoulaye 2012; Archie 2013). Similarly to reduced tillage, as the farmer ages, the crop rotation rate is expected to decrease by 0.343 , perhaps for the extra labour and change in working practice implied, normally assumed to be a bastion of the young.

Factors influencing the adoption of intercropping are Subsidies, Irrigation and Awareness2. As intercropping implies a greater cultivated area and hence greater water demand, thus those farmers who already have an established network for irrigation would be more likely to implement intercropping. Similarly to the uptake of cover crops, increased awareness of environmental welfare would also imply a greater likelihood that the practice would be adopted.

Several studies found that the farmers were not motivated to adopt mitigation or agrienvironmental practices if they did not receive compensation for implementing them (Poe et al. 2001; Bracht et al. 2008; Hellerstein et al. 2002). The financial incentive seems to be the most attractive option for the farmer's adoption decision (Prager and Posthumus 2010). Subsidies are significant to farmers and this variable is significant in practices that may receive direct or indirect financial incentives in the form of subsidies. Crop rotation is the only practice that currently receives direct subsidies in Aragon out of our six selected mitigation practices, however intercropping and cover crops may be eligible for subsidies when associated with legume species subject to the environmental commitment of the CAP. The practices that do not receive subsidies may require a higher level of private investment and therefore their implementation relies only on the possible economic benefit for the farmer. As most farmers 
already use fertilizer, a change to optimized fertilizer or animal manure does not necessary imply a great modification to the status quo and reduced tillage if anything requires less work and thus financial incentives for these practices are not so imperative.

\section{[INSERT TABLE 8 NEAR HERE]}

\section{CONCLUSIONS}

There are some major limitations of our findings. First, the study does not address the full range of mitigation practices. The list of selected mitigation practices is limited and only included the measures that are likely to be relevant in the region. This selection is based on the applicability of the practice given the current structure of the farming systems, agro-climatic limitations and the production factors of the case study. The selected measures addresses crop and soil mitigation, since over ninety percent of the farming systems are cropland. Livestock mitigation measures are not considered. Second, the expert panel for the MCA was only composed of academics and despite many of them belonging to policy committees and policy advisory boards; it could be more policy relevant to include the views of policy-makers, practitioners and farmers. The MCA included qualitative criteria, resulting in difficult comparison among experts' opinions. A derived shortcoming is that the qualitative criteria is limited in capturing variability among the respondents and beyond that, some of the qualitative criteria seem to be reasonable interlinked and overlapping; therefore the low variability of our results in the different climate scenarios may be a consequence of using qualitative criteria. In spite of this shortcoming, farmers are more likely to respond to qualitative than quantitative criteria when they perceive that the question is not directly related to their expertise. In addition some of the open questions provide limited information for the quantitative process. The key question of 
cost-effectiveness was not explicitly considered. As an alternative, the responses were used to estimate the effort to benefit ratio of each measure. Third, the survey sample is relatively small and it is not necessarily representative of the entire Aragon region, although, the gender, education and land holding structure are fairly in line with the region's demographics. It would be of great interest to conduct a similar study with a larger number of participants to consolidate our preliminary findings. Finally, the econometric models applied to the survey results only provide an evaluation of the effect - positive or negative - of the determinants on the adoption of practices and do not provide a monetary evaluation. The influence of different determinants on adoption of mitigation practices is a useful factor to define the measures that are likely to be adopted and evaluate barriers to implementation. Future research is needed in order to further understand the underlying reasons for adoption of mitigation practices and how local knowledge can be used in the wider policy context.

Despite these limitations, the analysis advances our knowledge of differing public support for climate change mitigation policy by providing increased comprehension of the variety of reasons farmers oppose or support mitigation policies and their relationship to the sociodemographic characteristics which could be used to predict mitigation policy support in a geographically and socially diverse area. The methodology developed could be applied on a larger scale, in different regions and under different climatic scenarios.

The study suggests that the design of agricultural mitigation strategies in Aragon must give additional importance to the adoption of agricultural practices such as cover crops in orchard systems and optimized fertilization. These were selected by the expert panel to be the most suitable practices under both the current climate and a supposed warmer, drier one given their capacity to improve water quality and enhance soil carbon sequestration. Both practices were widely accepted by experts and had a relatively low effort to benefit ratio in terms of implementation costs and mitigation potential. The results from the literature review suggest that the adoption of these practices could benefit the agricultural mitigation in Aragon by soil 
carbon sequestration rates ranging between $0.65-1.55 \mathrm{t} \mathrm{CO}_{2} \mathrm{ha}^{-1}$ per year for at least $7.5 \%$ of the total croplands and $0.36-0.62 \mathrm{t} \mathrm{CO}_{2} \mathrm{ha}^{-1}$ per year for all the croplands area. Furthermore, the adoption of optimized fertilization has been reported to contribute to the dissemination and transfer of knowledge of scientific research and innovation to the farmers by establishing a channel of communication where farmers can be made aware of such advances. No single strategy is completely effective and a combination of regional plans, advisory services, research and private measures, should be implemented.

Our results confirm the main findings of previous studies which have proposed that both financial and non-financial incentives affect the farmer's decision to adopt mitigation practices. The main factors influencing the adoption rate of the mitigation practices considered in this study were; whether or not financial subsidies were received, whether technical advice was readily available, whether political advice was accessible and the environmental concern of individual farmers. Thus the adoption of these practices should be encouraged with policy measures which include financial incentives while promoting environmental awareness and technical training. As these practices are widely seen to be advantageous, in terms of their mitigation potential and soil quality, it stands to reason that the better informed the farmers are, the more likely they are to adopt these beneficial practices. The dissemination of scientific advances, technical information and agricultural policies relating to these mitigation practices reach the farmers by extension services, however great improvements are needed given that current farm advisory services are limited and poorly funded (EC 2009b), especially in Spain. Finally, it is not surprising that financial incentives play an important role in encouraging the agricultural population to adopt cover crops, intercropping and crop rotation. Advisory services need interventions in order to ensure adequate access to policy and technical information, especially for the adoption of crop rotations, optimized fertilization, reduced or zero tillage and fertilization with animal manures. 
The results show that there is considerable potential for improving agricultural mitigation and support for mitigation policies in the region. Motivation and barriers are affected by demographic determinants, which indirectly influence individuals' support for mitigation policies (Iglesias et al. 2012b). In this study, the main socio-demographic determinant which affected farmers' likelihood of adoption is knowledge. Future work may consider a deeper assessment of farmers' attitude towards climate change as well as the role of socio-demographic determinants. Consequently, this would be particularly relevant for increasing farmers' education level in order to enhance support for mitigation policy. To this end, a choice modelling method based on farmers' opinion using field surveys seems to be particularly appropriate.

\section{ACKNOWLEDGEMENTS}

We acknowledge funding from the SmartSOIL project (Project number: 289694), EU, 7th Framework Programme, and the collaboration of experts of the REMEDIA network (www.remedia.org) and the collaboration with farmers of the farming cooperative "Virgen de la Corona" and of the association of conservation agriculture of Aragon "Agracon".

\section{REFERENCES}

Aguilera E, Lassaletta, L, Gattinger A, Gimeno BS (2013) Managing soil carbon for climate change mitigation and adaptation in Mediterranean cropping systems: A meta-analysis. Agric Ecosyst Environ 168: 25-36

Álvaro-Fuentes J, Cantero-Martínez C (2010) Potential to mitigate anthropogenic $\mathrm{CO}_{2}$ emissions by tillage reduction in dryland soils of Spain. Span J Agric Res 8(4): 1271-1276 
Álvaro-Fuentes J, Paustian K (2011) Potential soil carbon sequestration in a semiarid Mediterranean agroecosystem under climate change: Quantifying management and climate effects. Plant Soil 338: 261-272

Archie KM (2013) Mountain communities and climate change adaptation: barriers to planning and hurdles to implementation in the Southern Rocky Mountain Region of North America. Mitig Adapt Strateg Glob Chang (in press) DOI 10.1007/s110270139449

Badía D (2011) iARASOL, programa interactivo para el estudio y clasificación de suelos de Aragón. http://www.suelosdearagon.com/

Böhringer C, Rutherford TF, Tol RSJ (2009) The EU 20/20/2020 targets: An overview of the EMF22 assessment. Energy Econ 31, Supplement 2, S268-S273

Bracht J, Figuières C, Ratto M (2008) Relative Performance of Two Simple Incentive Mechanisms in a Public Goods Experiment. J Public Econ 92(1): 54-90

Bryan E, Deressa TT, Gbetibouo GA, Ringler C (2009) Adaptation to climate change in Ethiopia and South Africa: options and constraints. Environ Sci Policy 12: 413-426

Buse A (1982) The Likelihood Ratio, Wald and Lagrange Multiplier Tests: An Expository Note. Amer Statist 36(3a): 153-157

Cameron AC, Trivedi PK (1986) Econometric models based on count data. Comparisons and applications of some estimators and tests. J Appl Econ 1(1): 29-53

Cameron AC, Trivedi PK (2005) Microeconometrics: Methods and Applications. Cambridge University Press, New York 
Cary JW, Webb T, Barr NF (2001) The adoption of sustainable practices: Some new insights. An analysis of drivers and constraints for the adoption of sustainable practices derived from research. Land and Water Australia, Canberra

CEDEX (2011) Evaluación del Impacto del Cambio Climático en los Recursos Hídricos en Régimen Natural [Evaluation of the Impact of Climate Change in Water Resources under Natural Regime]. Centre of Public Works Studies and Experimentation, CEDEX, Madrid, Spain.

Czaja R, Blair J, (2005) Designing Surveys: A Guide to Decisions and Procedures, 2nd edn. Sage Publications, Thousand Oaks

De Leeuw ED (2005) To mix or not to mix data collection modes in surveys. J Off Stat 21(5): $233-255$

European Environment Agency (EEA) (2010) The European environment, State and outlook 2010. State of the environment report. European Environment Agency, Copenhagen

Eurobarometer Surveys on Climate Change (2011) European's Attitudes Towards Climate Change. Available at: http://ec.europa.eu/public_opinion/archives/ebs/ebs_372_en.pdf

European Commission (EC) (2009a) Decision No 406/2009/EC of the European Parliament and of the Council of 23 April 2009 on the effort of Member States to reduce their greenhouse gas emissions to meet the Community's greenhouse gas emission reduction commitments up to 2020. Off J Eur Union L140: 136-148

European Commission (EC) (2009b) The role of European agriculture in climate change mitigation. Commission Staff Working Document $N^{\circ}$ 1093. Final Commission of the European Communities, Brussels 
EUROSTAT (2013) Database. Structure of agricultural holdings 2010. http://epp.eurostat.ec.europa.eu/portal/page/portal/region_cities/regional_statistics/data/database $\underline{. \text { Cited } 15 \text { Jul } 2013}$

Feder G, Umali DL (1993) The adoption of agricultural innovations: a review. Technol Forecast Soc Change 43(3): 215-239

Fisher BS, Nakicenovic N, Alfsen K, CorfeeMorlot J, de la Chesnaye F, Hourcade J-Ch, Jiang K, Kainuma M, La Rovere E, Matysek A, Rana A, Riahi K, Richels R, Rose S, van Vuuren D, Warren R (2007) Issues related to mitigation in the long term context. In: Metz B, Davidson OR, Bosch PR, Dave R, Meyer LA (eds) Climate change 2007: mitigation. Contribution of working group III to the Fourth Assessment Report of the Intergovernmental Panel on Climate Change. Cambridge University Press, Cambridge, pp169-250.

Follet RF (2001) Soil management concepts and carbon sequestration in croplands soils. Soil Tillage Res 61(1): 77-92

Freibauer A, Rounsevell MD, Smith P, Verhagen J (2004) Carbon sequestration in the agricultural soils of Europe. Geoderma 122(1): 1-23

García de Jalón S, Iglesias A, Quiroga S, Bardají I (2013) Exploring public support for climate change adaptation policies in the Mediterranean region: A case study in Southern Spain. Environ Sci Policy 29: 1-11

Georgopoulou E, Sarafidis Y, Mirasgedis S, Zaimi S, Lalas DP (2003) A multiple criteria decision-aid approach in defining national priorities for greenhouse gases emissions reduction in the energy sector. Eur J Oper Res 146(1): 199-215

Gujarati D, Porter D (2009) Basic Econometrics, 5th edn. McGraw-Hill Irwin, New York 
Hanemann M, Labandeira X, Loureiro M (2011) Climate Change, Energy and Social Preferences on Policies: Exploratory Evidence for Spain. Clim Res 48: 343-348

Hellerstein D, Nickerson C, Cooper J, Feather P, Gadsby D, Mullarkey D, Tegene A, Barnard C (2002) Farmland protection: The role of public preferences for rural amenities. USDA Economic Research Service, Agricultural Economic Report No. 815.

Herrero J, Snyder RL (1997) Aridity and irrigation in Aragon, Spain. J Arid Environ 35(3): 535547

Iglesias A, Garrote L, Quiroga S, Moneo M (2012a) A regional comparison of the effects of climate change on agricultural crops in Europe. Clim Change 112: 29-46.

Iglesias A, Garrote L, Quiroga S, Moneo M (2012b) From climate change impacts to the development of adaptation strategies: challenges for agriculture in Europe. Clim Change 112: $143-168$.

Ingram J, Morris C (2007) The knowledge challenge within the transition towards sustainable soil management: An analysis of agricultural advisors in England. Land Use Policy 24(1): 100117

Isgin T, Bilgic A, Forster DL, Batte MT (2008) Using count data models to determine the factors affecting farmers' quantity decisions of precision farming technology adoption. Comput Electron Agr 62(2): 231-242.

Johnson RJ, Doye D, Lalman DL, Peel DS, Curry Raper K, Chung C (2010) Factors affecting adoption of recommended management practices in stocker cattle production. J Agr Appl Econ 42(1): $15-30$

Kahil MT, Albiac J (2013) Greenhouse gases mitigation policies in the agriculture of Aragon, Spain. Bio-based Appl. Econ 2(1): 49-72 
Kivlin JE, Filegel FC (1966) Attributes of Innovation as Factor in Diffusion. Am J Sociol 72: $235-248$

Klein RJT, Huq S, Denton F, Downing TE, Richels RG, Robinson JB, Toth FL (2007) Interrelationships between adaptation and mitigation. In: Parry ML, Canziani OF, Palutikof JP, van der Linden PJ, Hanson CE (eds) Climate change 2007: impacts, adaptation and vulnerability. Contribution of Working Group II to the Fourth Assessment Report of the Intergovernmental Panel on Climate Change. Cambridge University Press, Cambridge, pp745-777

Knowler D, Bradshaw B (2007) Farmers' Adoption of Conservation Agriculture: A Review and Synthesis of Recent Research. Food Pol 32(1): 25-48

Konidari P, Mavrakis D (2007) A multi-criteria evaluation method for climate change mitigation policy instruments. Energy Policy 35(12): 6235-6257

Lal R (1999) Global carbon pools and fluxes and the impact of agricultural intensification and judicious land use. Prevention of Land Degradation, Enhancement of Carbon Sequestration and Conservation of Biodiversity Through Land Use Change and Sustainable Land Management with a Focus on Latin America and the Caribbean. World Soil Resources Report 86. FAO, Rome, pp. 45- 52

Lal R (2004) Carbon sequestration in dryland ecosystems. Environ Manage 33(4): 528-544

Lal R, Bruce JP (1999) The potential of world cropland soils to sequester C and mitigate the greenhouse effect. Environ Sci Policy 2(2): 177-185

Lal R, Kimble JM (1997) Conservation tillage for carbon sequestration. Nutri Cycl Agroecosyst 49: $243-253$ 
Lecina S, Isidoro D, Playán E, Aragüés R (2010). Irrigation modernization and water conservation in Spain: The case of Riegos del Alto Aragón. Agric Water Manage 97(10):16631675

MAGRAMA (2012) Inventario de emisiones de gases de efecto invernadero de España e información adicional: 1990-2010 [Inventory of Spanish greenhouse gases emissions and additional information: 1990-2010]. Ministry of Agriculture, Food and Environment, Madrid, Spain

MAGRAMA (2013) Encuesta sobre Superficies y Rendimientos Cultivos. [Land use and Crop Yields Survey]. Ministry of Agriculture, Food and Environment, Madrid, Spain

Marsden T, Sonnino R (2008) Rural development and the regional state: Denying multifunctional agriculture in the UK. J Rural Stud 24(4): 422-431.

Morris C, Potter C (1995) Recruiting the New Conservationists: Farmers' Adoption of AgriEnvironmental Schemes in the UK. J Rural Stud 11(1): 51-63

Mustajoki J, Hämäläinen RP (2000) Web-HIPRE: global decision support by value tree and AHP analysis. INFOR 38(3): 208-220

Mustajoki J, Hämäläinen RP, Marttunen M (2004) Participatory multicriteria decision analysis with WebHIPRE: a case of lake regulation policy. Environ Model Softw 19(6):537-547

Nieto OM, Castro J, Fernandez-Ondono E (2013) Conventional tillage versus cover crops in relation to carbon fixation in Mediterranean olive cultivation. Plant Soil 365: 321-335

Ninyerola M., Pons X, Roure JM (2005) Atlas climático digital de la península ibérica. Metodología y aplicaciones en bioclimatología y geobotánica. Universidad Autónoma de Barcelona, Bellaterra 
Norris PE, Batie SS (1987) Virginia farmers' soil conservation decisions: an application of Tobit analysis. South J Agric Econ 19(1): 79-89

OECD (2012), Farmer Behaviour, Agricultural Management and Climate Change, OECD Publishing. Available at: http://dx.doi.org/10.1787/9789264167650-en. Cited 10 Jan 2013

Ogle SM, Breidt FJ, Paustian K (2005) Agricultural management impacts on soil organic carbon storage under moist and dry climatic conditions of temperate and tropical regions. Biogeochemistry 72: 87-121

Pachauri RK, Reisinger A (2007) Climate change 2007: synthesis report. IPCC, Geneva

Paustian K, Collins HP, Paul EA (1997) Management controls on soil carbon P. In: Paul EA, Paustian K, Elliott ET, Cole CV (eds) Soil organic matter in temperate agroecosystems. CRC Press, Boca Raton, Florida, pp15-49

Poe GL, Bills NL, Bellows BC, Crosscombe P, Koelsch RK, Kreher MJ, Wright P (2001) Will Voluntary and Educational Programs Meet Environmental Objectives: Evidence From a Survey of New York Dairy Farms. Rev Agr Econ 23(2): 473-491

Prager K, Posthumus H (2010) Socio-economic factors influencing farmers' adoption of soil conservation practices in Europe. In: Napier TL (ed) Human Dimensions of Soil and Water Conservation. Nova Science Publishers Inc, New York, pp203-223

Prokopy L, Floress SK, Klotthor-Weinkauf D, Baumgart-Getz A (2008) Determinants of Agricultural Best Management Practice Adoption: Evidence from the Literature. J Soil Water Conserv 63(5): 300-311

Rahelizatovo NC, Gillespie, JM (2004) The adoption of best-management practices by Louisiana dairy producers. J Agr Appl Econ 36(1): 229-240 
Smith P (2004) Carbon sequestration in croplands: the potential in Europe and the global context. Eur J Agron 20(3): 229-236

Smith P, Martino D, Cai Z, Gwary D, Janzen H, Kumar P, McCarl B, Ogle S, O'Mara F, Rice C (2007a) Policy and technological constraints to implementation of greenhouse gas mitigation options in agriculture. Agric Ecosyst Environ 118(1): 6-28

Smith P, Martino D, Cai Z, Gwary D, Janzen H, Kumar P, McCarl B, Ogle S, O’Mara F, Rice C, Scholes B, Sirotenko O (2007b) Agriculture. In: Metz B, Davidson OR, Bosch PR, Dave R, Meyer LA (eds) Climate Change 2007: mitigation. Contribution of Working Group III to the Fourth Assessment Report of the Intergovernmental Panel on Climate Change. Cambridge University Press, Cambridge, pp497-540.

Smith P, Martino D, Cai Z, Gwary D, Janzen H, Kumar P, McCarl B, Ogle S, O'Mara F, Rice C, Scholes B, Sirotenko O, Howden M, McAllister T, Pan G, Romanenkov V, Dchneider U, Towprayoon S, Wattenbach M, Smith J (2008) Greenhouse gas mitigation in agriculture. Phil Trans R Soc B 363(1492): 789-813

Smith P, Powlson DS, Glendinning MJ, Smith JU (1997) Potential for carbon sequestration in European soils: preliminary estimates for five scenarios using results from long-term experiments. Glob Chang Biol 3(1): 67-79

Snyder CS, Bruulsema TW, Jensen TL, Fixen PE (2009) Review of greenhouse gas emissions from crop production systems and fertilizer management effects. Agric Ecosyst Environ 133(3): $247-266$

Soane BD, Ball BC, Arvidsson J, Basch G, Moreno F, Roger-Strade J (2012) No-till in northern, western and south-western Europe: A review of problems and opportunities for crop production and the environment. Soil Tillage Res 118: 66-87 
Steenwerth K, Belina KM (2008) Cover crops enhance soil organic matter, carbon dynamics and microbial function in a vineyard agroecosystem. Appl Soil Ecol 40(2): 359-369

Stern N (2007) The Economics of Climate Change: the Stern Review. Cambridge University Press, Cambridge

Sunding D, Zilberman D (2001) The agricultural innovation process: research and technology adoption in a changing agricultural sector. In: Gardner BL, Rausser GC (Eds.) Agricultural Production, Handbook of Agricultural Economics, vol. 1, Elsevier, New York, pp207-261

Tambo JA, Abdoulaye T (2012) Climate change and agricultural technology adoption: the case of drought tolerant maize in rural Nigeria. Mitig Adapt Strateg Glob Chang 17(3): 277-292

UNFCCC (2008) Challenges and opportunities for mitigation in the agricultural sector: technical paper. United Nation Framework Convention on Climate Change. Available at: http://unfccc.int/resource/docs/2008/tp/08.pdf. Cited 17 Mar 2013

UNFCCC (2011) Assessing the costs and benefits of adaptation options. The Nairobi Work Programme on impacts, vulnerability and adaptation to climate change. United Nations Framework Convention on Climate Change. Available at: http://unfccc.int/resource/docs/publications/pub_nwp_costs_benefits_adaptation.pdf. Cited 2 Jul 2013

Ward CE, Vestal MK, Doye DG, Lalman DL (2008) Factors affecting adoption of cow-calf production practices in Oklahoma. J Agr Appl Econ 40(3): 851-863

West TO, Post WM (2002) Soil organic carbon sequestration rates by tillage and crop rotations: A global data analysis. Soil Sci Soc Am J 66(6): 1930-1946

Yagüe MR, Quílez D (2010) Cumulative and residual effects of swine slurry and mineral nitrogen in irrigated maize. Agron J 102: 1682-1691 


\section{FIGURE LEGENDS}

Figure 1: Methodology framework used in this study.

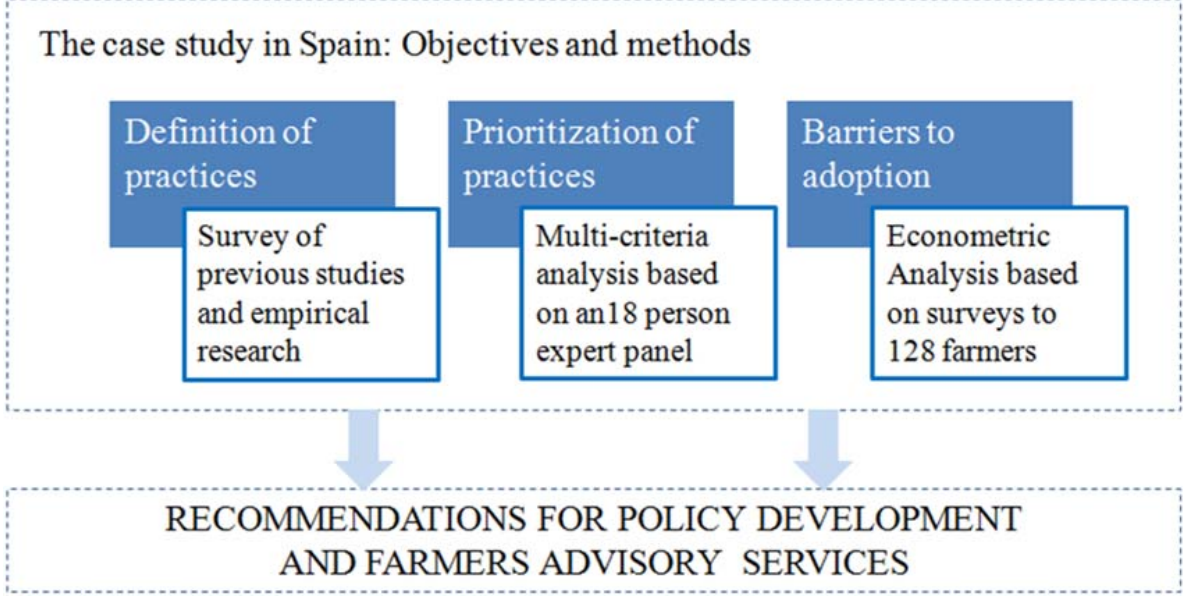

Figure 2. Analytical Hierarchy Process diagram of the study. The goal was to select the most suitable mitigation practice from the six considered agricultural practices. Criteria, against which each mitigation practice was measured by the expert panel, were classified into economic, social and environmental criteria.

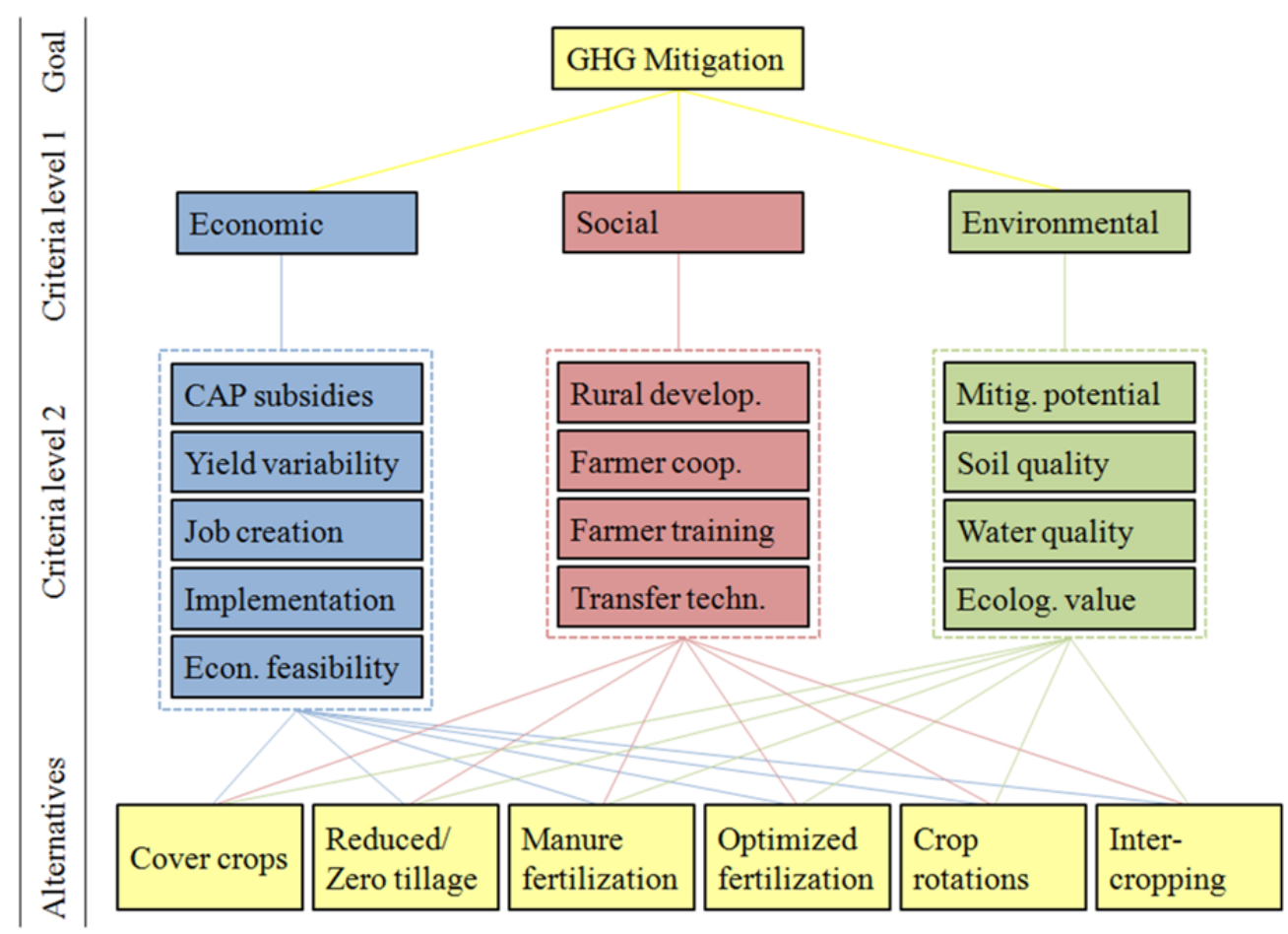


Figure 3. Map showing the location and distribution of the sampled holdings. Figure 3a shows the Iberian Peninsula with the north-eastern autonomous community of Aragon highlighted. Figure $3 \mathrm{~b}$ further divides the region into its 3 provinces, from north to south, Huesca, Zaragoza and Teruel.
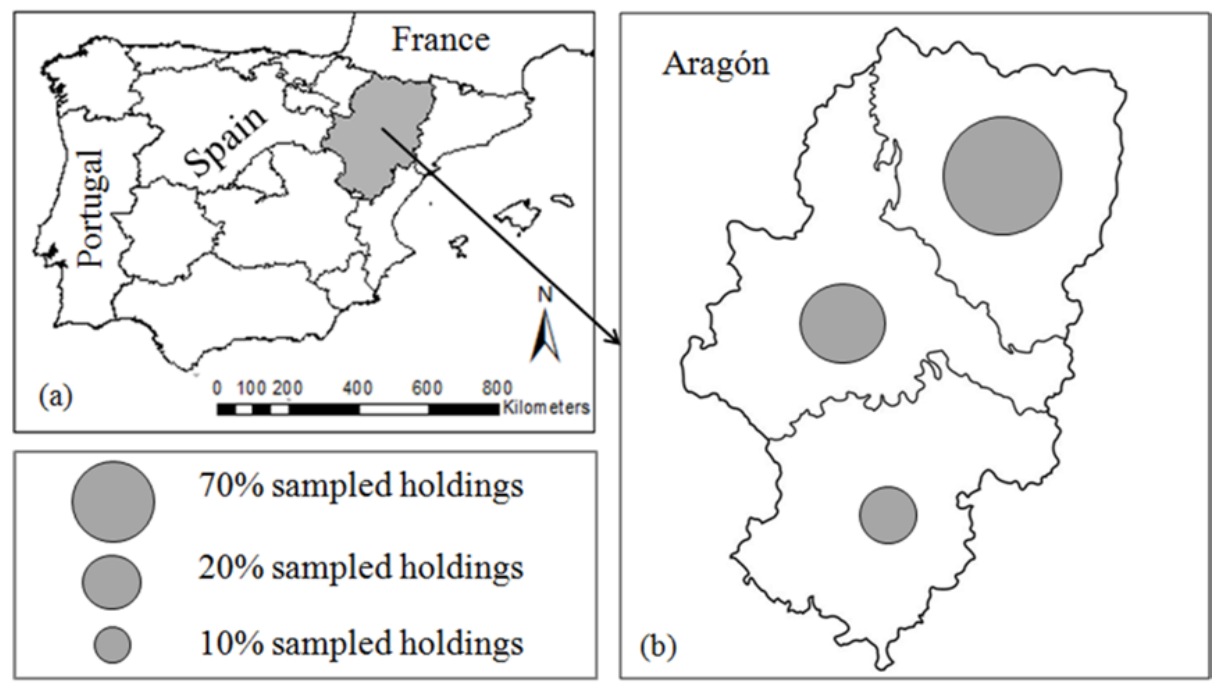

Figure 4. Feasibility of the selected mitigation practices according to the expert panel and questionnaire results based on qualitative value judgments of experts.

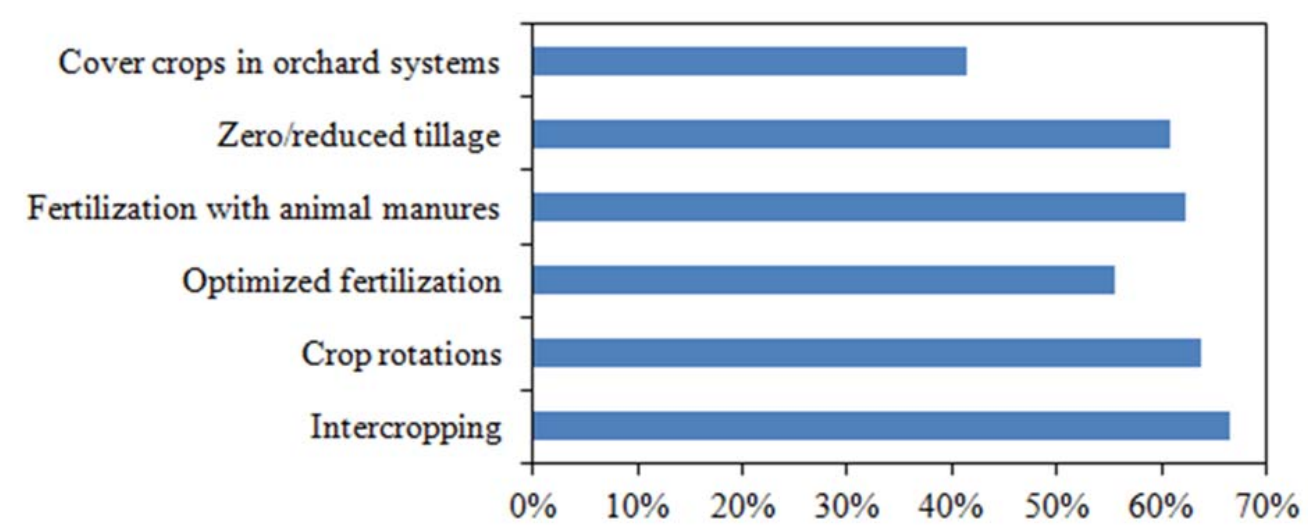


Figure 5. Analysis of composite priorities of the selected mitigation practices under different scenarios by expert criteria.

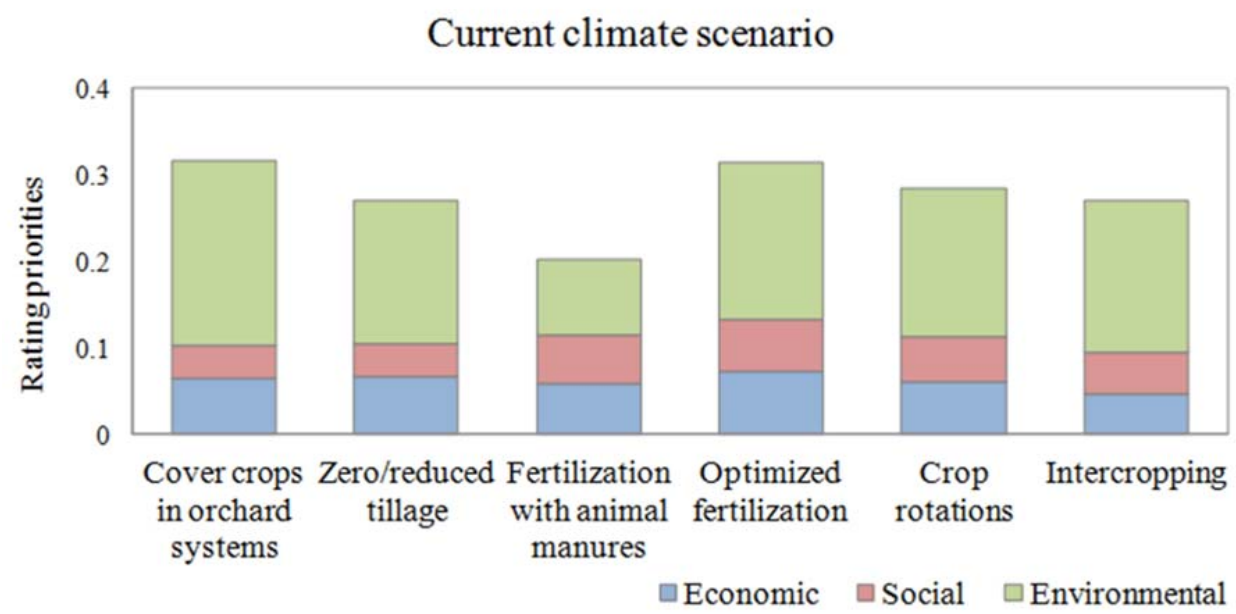

Climate change scenario

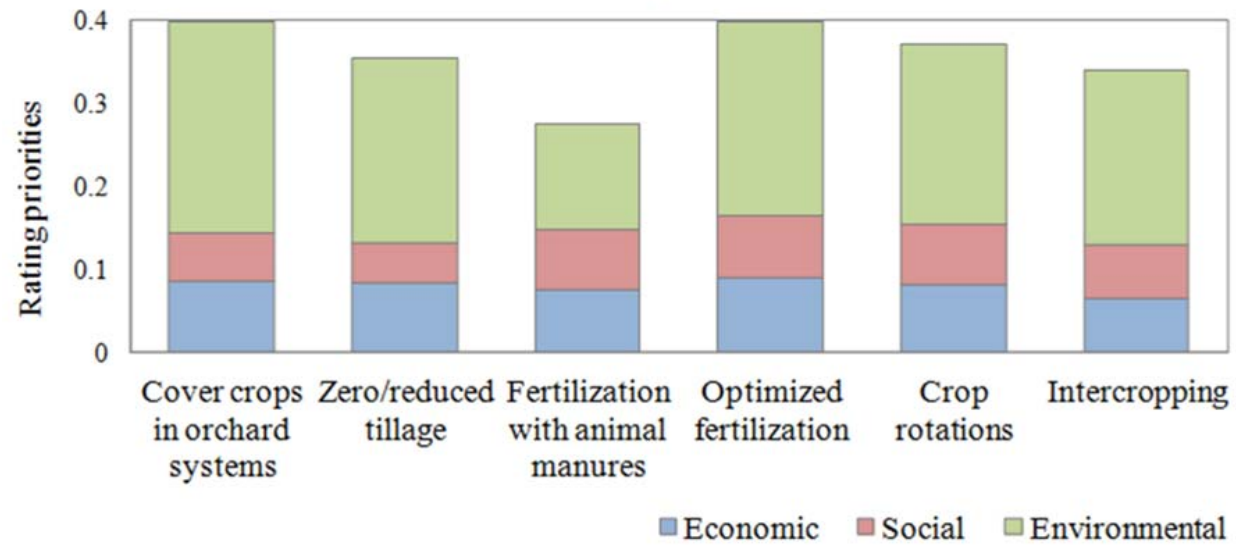


Figure 6: Effort to benefit ratio for the six selected mitigation measures.

Current climate scenario

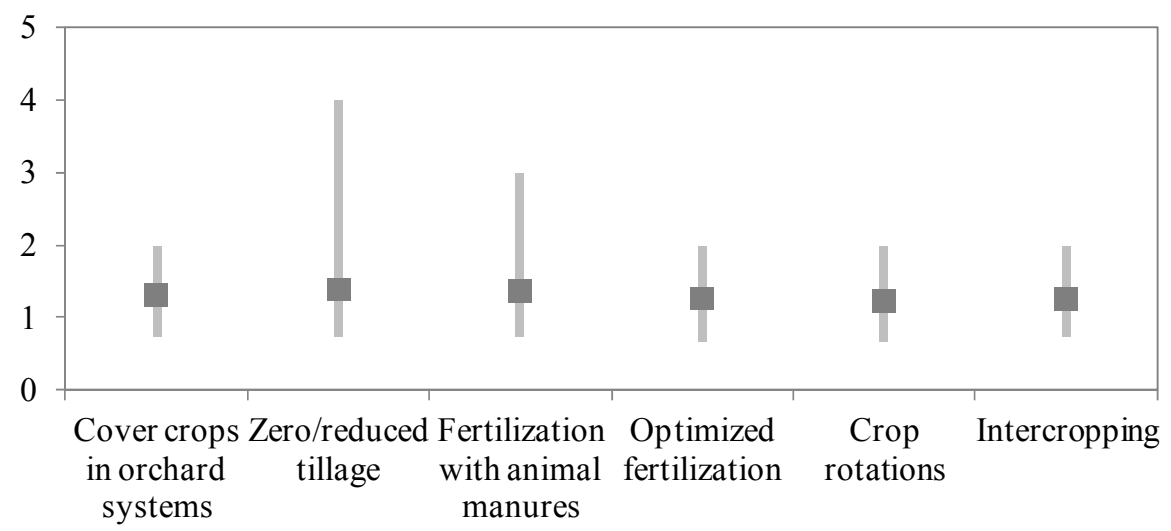

Climate change scenario

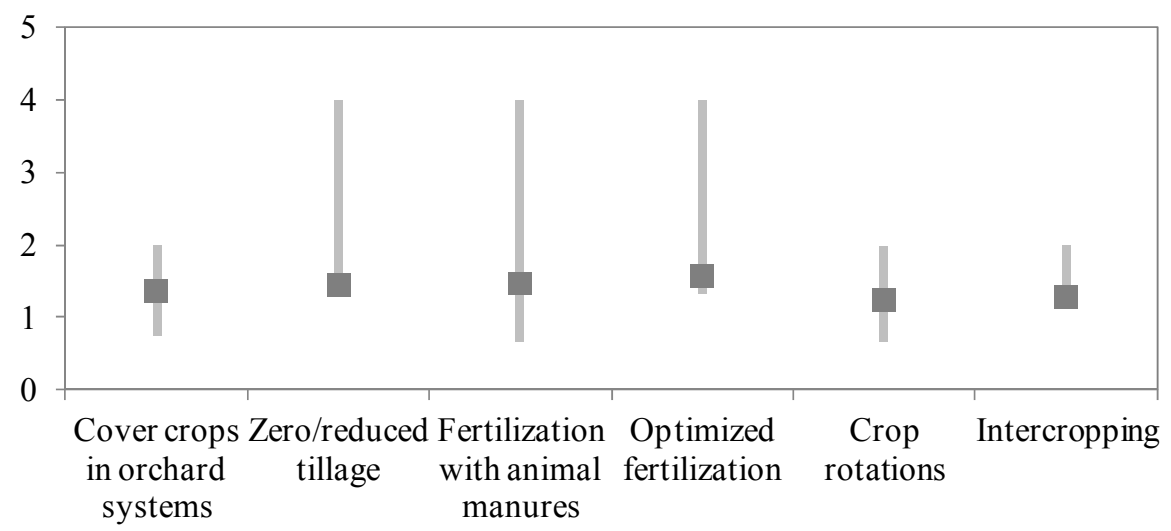




\section{TABLES}

Table 1. Detailed description of the six selected mitigation practices for this case study

\begin{tabular}{|c|c|c|c|}
\hline $\begin{array}{l}\text { Mitigation } \\
\text { measures } \\
\text { considered }\end{array}$ & Description of the mitigation measure & $\begin{array}{l}\text { Potential soil carbon } \\
\text { sequestration rate } \\
\left(\mathrm{tCO} 2 \mathrm{ha}^{-1} \text { year) }\right.\end{array}$ & Sources \\
\hline $\begin{array}{l}\text { Cover crops } \\
\text { in orchard } \\
\text { systems }\end{array}$ & $\begin{array}{l}\text { This mitigation measure consists of } \\
\text { intercropping spontaneous or human } \\
\text { induced cover crops with farmland } \\
\text { trees in order to improve soil fertility } \\
\text { and water use. It also enhances soil } \\
\text { carbon stores thereby increasing the } \\
\text { carbon sequestration rate. }\end{array}$ & $0.65-1.55$ & $\begin{array}{l}\text { Lal and Bruce 1999; } \\
\text { Steenwerth and Belina } \\
\text { 2008; Nieto et al. } 2013\end{array}$ \\
\hline $\begin{array}{l}\text { Reduced } \\
\text { tillage / no- } \\
\text { tillage }\end{array}$ & $\begin{array}{l}\text { Reducing or avoiding tillage } \\
\text { practices, increase soil carbon storage } \\
\text { through reducing microbial } \\
\text { decomposition, and promoting crop } \\
\text { residue incorporation into soil. }\end{array}$ & $0.23-0.71$ & $\begin{array}{l}\text { Lal and Kimble 1997; } \\
\text { Lal and Bruce 1999; } \\
\text { Follet 2001; Ogle et al. } \\
\text { 2005; Smith et al. 2008; } \\
\text { Álvaro-Fuentes and } \\
\text { Cantero-Martínez 2010. }\end{array}$ \\
\hline $\begin{array}{l}\text { Fertilization } \\
\text { with animal } \\
\text { manures }\end{array}$ & $\begin{array}{l}\text { Incorporating animal manures to the } \\
\text { soil, increases organic carbon stores } \\
\text { and enhances carbon return to the soil, } \\
\text { thereby encouraging carbon } \\
\text { sequestration. }\end{array}$ & $0.1-0.33$ & $\begin{array}{l}\text { Paustian et al. 1997; } \\
\text { Smith et al. 1997; Follet } \\
\text { 2001; Smith et al. 2008; } \\
\text { Freibauer et al. } 2004 \text {; }\end{array}$ \\
\hline $\begin{array}{l}\text { Optimized } \\
\text { fertilization }\end{array}$ & $\begin{array}{l}\text { Changes in application rates, fertilizer } \\
\text { placement or split applications } \\
\text { depending on crop needs increases } \\
\text { efficiency thus reducing GHG } \\
\text { emissions, especially nitrous oxide. }\end{array}$ & $0.36-0.62$ & $\begin{array}{l}\text { Lal and Bruce 1999; } \\
\text { Follet 2001; Snyder et } \\
\text { al. } 2009\end{array}$ \\
\hline $\begin{array}{l}\text { Crop } \\
\text { rotations }\end{array}$ & $\begin{array}{l}\text { Using crop rotations in the same plot, } \\
\text { increases soil carbon stores and } \\
\text { requires reduced fertilizer use, thereby } \\
\text { reducing nitrous oxide emissions. }\end{array}$ & $0.08-1.6$ & $\begin{array}{l}\text { Lal and Bruce 1999; } \\
\text { Follet 2001; West and } \\
\text { Post 2002; Lal } 2004\end{array}$ \\
\hline Intercropping & $\begin{array}{l}\text { Combining two crops during the same } \\
\text { growing season improves soil fertility } \\
\text { and soil carbon storage due to more } \\
\text { efficient nutrient use and reducing } \\
\text { fertilizers application rate as well as } \\
\text { GHG emissions. }\end{array}$ & $\begin{array}{l}0.01-0.03 \\
\text { (from mulch } \\
\text { farming) }\end{array}$ & $\begin{array}{l}\text { Paustian et al. 1997; Lal } \\
\text { and Bruce 1999; Lal } \\
\text { 1999; Lal 2004; } \\
\text { Freibauer et al. } 2004\end{array}$ \\
\hline
\end{tabular}


Table 2. Statistical summary of dependent variables for the Poisson (Mitigatpractices), the negative binomial (Mitigatpractices) and the logit binomial models (Covercrops, Notillage, Animalmanures, Optifertilization, Croprotations and Intercropping). The Independent variables are common across all models.

\begin{tabular}{|c|c|c|c|}
\hline \multicolumn{2}{|c|}{ Category/Variable Description } & Mean & SD \\
\hline \multicolumn{4}{|c|}{ Dependant variable } \\
\hline Covercrops & Practice is implemented $(1=$ yes, $0=$ no or not sure $)$ & 0.21 & 0.41 \\
\hline Notillage & Practice is implemented $(1=$ yes, $0=$ no or not sure $)$ & 0.63 & 0.48 \\
\hline Animalmanures & Practice is implemented ( $1=$ yes, $0=$ no or not sure $)$ & 0.50 & 0.50 \\
\hline Optifertilization & Practice is implemented $(1=$ yes, $0=$ no or not sure $)$ & 0.46 & 0.50 \\
\hline Croprotations & Practice is implemented $(1=$ yes, $0=$ no or not sure $)$ & 0.68 & 0.46 \\
\hline Intercropping & Practice is implemented $(1=$ yes, $0=$ no or not sure $)$ & 0.31 & 0.46 \\
\hline Mitigatpractices & Adoption intensity of mitigation practices (taking on values from 0 to 6 ) & 2.82 & 1.75 \\
\hline \multicolumn{4}{|c|}{ Independent Variable } \\
\hline Age & Age of farmer in years $(1=$ less than $35,0=36$ or more $)$ & 0.15 & 0.36 \\
\hline Education & $\begin{array}{l}\text { Farmer having a technical education }(1=\text { technical degree, } 0=\text { no } \\
\text { technical degree) }\end{array}$ & 0.57 & 0.49 \\
\hline Landowner & Farmer being owner of the farm land $(1=$ yes, $0=$ no $)$ & 0.92 & 0.25 \\
\hline Size & $\begin{array}{l}\text { Size of farm in hectares }(1=\text { size }<10 \text { ha, } 2=10-50 \text { ha, } 3=50-100 \text { ha, } 4 \\
=\text { size }>100 \text { ha })\end{array}$ & 2.97 & 1.06 \\
\hline Irrigation & $\begin{array}{l}\text { Irrigation intensity }(1=\text { low or non-irrigated land, } 2=\text { medium, } 3= \\
\text { high) }\end{array}$ & 1.96 & 0.57 \\
\hline Subsidies & $\begin{array}{l}\text { Farm subsidy received by implementing mitigation practices }(1=\text { yes, } 0 \\
=\text { no or not sure) }\end{array}$ & 0.19 & 0.39 \\
\hline Techadvice & $\begin{array}{l}\text { Advice received about the mitigation practices management }(1=\text { yes, } 0 \\
=\text { no or not sure })\end{array}$ & 0.53 & 0.50 \\
\hline Pacadvice & $\begin{array}{l}\text { Advice received about the Common Agricultural Policy }(1=\text { yes, } 0=\text { no } \\
\text { or not sure) }\end{array}$ & 0.22 & 0.42 \\
\hline Awareness1 & $\begin{array}{l}\text { Agricultural policy concern for the adoption of mitigation practices }(1= \\
\text { yes, } 0=\text { no or not sure) }\end{array}$ & 0.67 & 0.46 \\
\hline Awareness 2 & $\begin{array}{l}\text { Environmental concern for the adoption of mitigation practices }(1=\text { yes, } \\
0=\text { no or not sure })\end{array}$ & 0.54 & 0.49 \\
\hline $\mathrm{SD}$ is standard de & iation. Total number of observations $=128$ & & \\
\hline
\end{tabular}


Table 3: The allocation of weights to the relative importance of criteria and sub-criteria by the expert judgment

\begin{tabular}{llll}
\hline Criteria weights & & Sub-Criteria weights \\
\hline Economic & 35 & CAP subsidies & 64 \\
& & Yield variability & 81 \\
& & Job creation & 72 \\
& & Implementation cost & 77 \\
& & Economic feasibility & 83 \\
Social & \multirow{2}{*}{21} & Rural development & 74 \\
& & Farmer cooper. level & 63 \\
& & Farmer training level & 74 \\
& & Transfer technology & 72 \\
Environmental & 44 & Mitigation potential & 90 \\
& & Soil quality & 87 \\
& & Water quality & 86 \\
& & Ecologic value & 79 \\
\hline
\end{tabular}

Table 4. Adoption rates of mitigation practices by farmers sampled in Aragon

\begin{tabular}{lll}
\hline Mitigation practice & Numbers adopted & Percentage adopted \\
\hline A1.Cover crops in orchard systems & 28 & 21.9 \\
A2.Reduced tillage / no-tillage & 81 & 63.3 \\
A3.Fertilization with animal manures & 65 & 50.8 \\
A4.Optimized fertilization & 59 & 46.1 \\
A5.Crop rotations & 88 & 68.8 \\
A6.Intercropping & 40 & 31.3 \\
\hline
\end{tabular}

Table 5. Frequency distribution of mitigation practice adoption amongst sampled farmers

\begin{tabular}{lll}
\hline Mitigation practice counts & Frequency & Relative frequency \\
\hline 0 & 13 & 0.101 \\
1 & 24 & 0.187 \\
2 & 18 & 0.140 \\
3 & 23 & 0.179 \\
4 & 28 & 0.218 \\
5 & 12 & 0.093 \\
6 & 10 & 0.078 \\
Total & 128 & 1 \\
\hline${ }^{1}$ Out of 128 farmers sampled, 115 adopted one or more practices & \\
\hline
\end{tabular}


Table 6. Coefficient estimates of the Poisson and Negative Binomial Regressions

\begin{tabular}{lllll}
\hline & \multicolumn{2}{c}{ Poisson } & \multicolumn{2}{c}{ Negative Binomial } \\
\hline Variable & Coefficient & Standard error & Coefficient & Standard error \\
\hline Constant & 0.232 & 0.305 & 0.273 & 0.341 \\
Age & -0.117 & 0.133 & -0.200 & 0.140 \\
Education & 0.112 & 0.103 & 0.147 & 0.111 \\
Landowner & -0.093 & 0.167 & 0.011 & 0.210 \\
Size & 0.015 & 0.051 & 0.005 & 0.052 \\
Irrigation & 0.049 & 0.087 & 0.011 & 0.107 \\
Subsidies & $0.330^{* * *}$ & 0.092 & $0.346^{* * *}$ & 0.111 \\
Techadvice & $0.398^{* * *}$ & 0.112 & $0.399^{* * *}$ & 0.115 \\
Pacadvice & $0.195^{* *}$ & 0.088 & $0.200^{*}$ & 0.105 \\
Awareness 1 & 0.146 & 0.110 & 0.082 & 0.119 \\
Awareness2 & $0.376^{* * *}$ & 0.109 & $0.371^{* * *}$ & 0.117 \\
\hline Number of observations & 128 & & 128 & \\
ln L & -227.30 & & -274.41 & \\
Pseudo ${ }^{2}$ & 0.100 & & & \\
Wald Prob $>$ chi2 & 0.000 & & - & \\
${ }^{1}$ Deviance Prob $>$ chi $^{2}$ & 0.382 & & - & \\
${ }^{1}$ Pearson Prob $>$ chi $^{2}$ & 0.847 & & & \\
${ }^{1}$ Goodness-of-fit (Cameron and Trivedi 1986);Significant level of $10 \%(*), 5 \%(*)$ and $1 \%(* * *) ;$
\end{tabular}

Table 7. Marginal effects for the Poisson Regression

\begin{tabular}{lll}
\hline Variable & Coefficient & Standard error \\
\hline Age & -0.296 & 0.323 \\
Education & 0.294 & 0.269 \\
Landowner & -0.254 & 0.476 \\
Size & 0.040 & 0.135 \\
Irrigation & 0.130 & 0.230 \\
Subsidies & $0.996^{* * *}$ & 0.292 \\
Techadvice & $1.038^{* * *}$ & 0.276 \\
Pacadvice & $0.541^{* *}$ & 0.255 \\
Awareness1 & 0.375 & 0.271 \\
Awareness2 & $0.978^{* * *}$ & 0.268 \\
\hline Significant level of $10 \%(*), 5 \%(* *)$ and $1 \%(* *)$
\end{tabular}


Table 8.a. Coefficient estimates and marginal effects of the Binomial Regressions

\begin{tabular}{|c|c|c|c|c|c|c|}
\hline \multirow[b]{2}{*}{$\begin{array}{l}\text { Independent } \\
\text { variable }\end{array}$} & \multicolumn{2}{|c|}{$\begin{array}{c}\text { Cover crops in orchard } \\
\text { systems }\end{array}$} & \multicolumn{2}{|c|}{ Reduced tillage/no-tillage } & \multicolumn{2}{|c|}{$\begin{array}{c}\text { Fertilization with animal } \\
\text { manures }\end{array}$} \\
\hline & Coefficient & $\begin{array}{l}\text { Marginal } \\
\text { effects }\end{array}$ & Coefficient & $\begin{array}{l}\text { Marginal } \\
\text { effects }\end{array}$ & Coefficient & $\begin{array}{l}\text { Marginal } \\
\text { effects }\end{array}$ \\
\hline Constant & $-1.201(1.593)$ & & $-1.384(1.455)$ & & $-2.975(1.250)$ & \\
\hline Age & $-1.031(0.814)$ & $-0.109(0.065)$ & $-1.522(0.580)^{* * *}$ & $-0.357(0.131)$ & $0.916(0.570)$ & $0.218(0.124)$ \\
\hline Education & $0.752(0.569)$ & $0.097(0.074)$ & $0.654(0.479)$ & $0.141(0.105)$ & $-0.413(0.441)$ & $-0.102(0.109)$ \\
\hline Landowner & $-1.684(0.824)^{* *}$ & $-0.332(0.187)$ & $-0.244(0.690)$ & $-0.050(0.135)$ & $0.560(0.770)$ & $0.137(0.182)$ \\
\hline Size & $-0.271(0.277)$ & $-0.036(0.036)$ & $0.422(0.224)^{*}$ & $0.090(0.047)$ & $0.127(0.205)$ & $0.0319(0.051)$ \\
\hline Irrigation & $-0.144(0.419)$ & $-0.019(0.056)$ & $-0.068(0.431)$ & $-0.014(0.092)$ & $0.512(0.371)$ & $0.128(0.092)$ \\
\hline Subsidies & $1.536(0.526)^{* * *}$ & $0.272(0.108)$ & $1.127(0.825)$ & $0.205(0.117)$ & $-0.206(0.500)$ & $-0.051(0.124)$ \\
\hline Techadvice & $0.830(0.603)$ & $0.110(0.071)$ & $1.273(0.475)^{* * *}$ & $0.271(0.098)$ & $1.284(0.439)^{* * *}$ & $0.310(0.099)$ \\
\hline Pacadvice & $-0.084(0.580)$ & $-0.011(0.075)$ & $0.932(0.524)^{*}$ & $0.177(0.089)$ & $0.819(0.503)$ & $0.198(0.115)$ \\
\hline Awareness 1 & $0.773(0.632)$ & $0.095(0.068)$ & $-0.195(0.550)$ & $-0.041(0.113)$ & $0.053(0.467)$ & $0.013(0.116)$ \\
\hline Awareness2 & $1.233(0.626)^{* *}$ & $0.161(0.075)$ & $0.306(0.503)$ & $0.065(0.107)$ & $0.595(0.471)$ & $0.147(0.115)$ \\
\hline $\begin{array}{l}\text { Likelihood } \\
\text { ratio }\end{array}$ & -55.26 & & -66.20 & & -75.62 & \\
\hline Observations & 128 & 128 & 128 & 128 & 128 & 128 \\
\hline
\end{tabular}

Standard errors are in parenthesis; Significant level of $10 \%(*), 5 \%(* *)$ and $1 \%(* * *)$

Table 8.b. Coefficient estimates and marginal effects of the Binomial Regressions

\begin{tabular}{|c|c|c|c|c|c|c|}
\hline \multirow[b]{2}{*}{$\begin{array}{l}\text { Independent } \\
\text { variable }\end{array}$} & \multicolumn{2}{|c|}{ Optimized fertilization } & \multicolumn{2}{|c|}{ Crop rotations } & \multicolumn{2}{|c|}{ Intercropping } \\
\hline & Coefficient & $\begin{array}{l}\text { Marginal } \\
\text { effects }\end{array}$ & Coefficient & $\begin{array}{l}\text { Marginal } \\
\text { effects }\end{array}$ & Coefficient & $\begin{array}{l}\text { Marginal } \\
\text { effects }\end{array}$ \\
\hline Constant & $-0.964(1.282)$ & & $-0.710(1.411)$ & & $-4.969(2.00)$ & \\
\hline Age & $-0.165(0.538)$ & $-0.040(0.131)$ & $-1.555(0.608)^{* *}$ & $-0.343(0.139)$ & $0.331(0.631)$ & $0.066(0.131)$ \\
\hline Education & $0.535(0.423)$ & $0.131(0.102)$ & $0.901(0.508)^{*}$ & $0.171(0.095)$ & $-0.452(0.550)$ & $-0.087(0.104)$ \\
\hline Landowner & $0.162(0.758)$ & $0.040(0.184)$ & $0.876(0.714)$ & $0.188(0.166)$ & $-1.441(0.961)$ & $-0.330(0.231)$ \\
\hline Size & $-0.289(0.231)$ & $-0.071(0.057)$ & $-0.140(0.247)$ & $-0.025(0.045)$ & $0.325(0.279)$ & $0.062(0.050)$ \\
\hline Irrigation & $-0.253(0.377)$ & $-0.062(0.093)$ & $-0.313(0.479)$ & $-0.057(0.086)$ & $1.118(0.359)^{* * *}$ & $0.213(0.070)$ \\
\hline Subsidies & $0.641(0.514)$ & $0.159(0.125)$ & $1.353(0.707)^{*}$ & $0.197(0.079)$ & $2.749(0.608)^{* * *}$ & $0.591(0.104)$ \\
\hline Techadvice & $1.097(0.427)^{* * *}$ & $0.264(0.097)$ & $0.811(0.513)$ & $0.151(0.096)$ & $0.061(0.493)$ & $0.011(0.093)$ \\
\hline Pacadvice & $0.976(0.521)^{*}$ & $0.238(0.121)$ & $1.597(0.513)^{* * *}$ & $0.230(0.064)$ & $-0.164(0.490)$ & $-0.030(0.090)$ \\
\hline Awareness 1 & $0.500(0.528)$ & $0.122(0.125)$ & $0.155(0.520)$ & $0.029(0.098)$ & $0.888(0.664)$ & $0.155(0.099)$ \\
\hline Awareness2 & $0.769(0.508)$ & $0.187(0.119)$ & $1.122(0.465)^{* *}$ & $0.210(0.088)$ & $2.098(0.732)^{* * *}$ & $0.372(0.103)$ \\
\hline $\begin{array}{l}\text { Likelihood } \\
\text { ratio }\end{array}$ & -75.35 & & -62.42 & & -59.06 & \\
\hline Observations & 128 & 128 & 128 & 128 & 128 & 128 \\
\hline
\end{tabular}

Standard errors are in parenthesis; Significant level of $10 \%(*), 5 \%(* *)$ and $1 \%(* * *)$ 